Discussion Paper No. 678

\title{
ENDOGENOUS TRADE POLICY: \\ POLITICAL STRUGGLE IN THE GROWTH PROCESS
}

\author{
Yoshiaki Sugimoto
}

December 2006

The Institute of Social and Economic Research

Osaka University

6-1 Mihogaoka, Ibaraki, Osaka 567-0047, Japan 


\title{
Endogenous Trade Policy: Political Struggle in the Growth Process
}

\author{
Yoshiaki Sugimoto*
}

December 21, 2006

\begin{abstract}
This paper develops a dynamic theory that accounts for the evolution of trade policy, underlying internal class conflicts, and output growth performance over the last few centuries. By analyzing political responses to the distributional effects of international trade, it finds a prominent interaction between trade policy and the pattern of economic development, and also a significant role for trade liberalization in economic take-off. Consistent with historical evidence for Western Europe, land-scarce economies reach a developed stage through the ebb and flow of liberalism. In contrast, land-abundant countries tend to stagnate because of landlords' opposition to industrialization.
\end{abstract}

Keywords: Trade Policy, Growth, Class Conflict.

JEL Classification: F10, F13, F43, O11, O40.

\footnotetext{
*Institute of Social and Economic Research, Osaka University, 6-1 Mihogaoka, Ibaraki, Osaka 567-0047, Japan; E-mail: sugimoto@iser.osaka-u.ac.jp I am grateful to Oded Galor, Wolfgang Keller, Pravin Krishna, Omar Licandro, and seminar participants at Brown University, the European University Institute, Kobe University, the National Graduate Institute for Policy Studies, Osaka University, and the University of Tokyo for useful comments and encouragement. In addition, I wish to thank Daniel Mejia and Jeffrey G. Williamson for supplying data. This research is supported by a JSPS Grant-in-Aid for Scientific Research (No. 18830036).
} 


\section{Introduction}

Over the last two centuries, the world economy has witnessed two epochal phenomena never seen before: the rapid expansion of international trade and the emergence of income gaps between nations. The approximate growth rate of intercontinental trade was $3.5 \%$ per annum in this period, while the figure was 1.1\% per annum between 1500 and 1800 (O'Rourke and Williamson 2001, Table 1). The gap between the West and the rest of the world in average per capita GDP was nearly 2:1 in 1820, whereas it was as much as 7:1 in 1998 (Maddison 2001, Table 1-9b, 46).

While these figures have brought a potential link between international trade and long-run growth performance to many economists' attention, there seems to be no established theory that accounts for their historical relationship. As pointed out by Williamson (2003), the role of international trade has typically been neglected by the recent literature that analyzes the transition from Malthusian stagnation to modern growth. ${ }^{1}$ Even the few exceptions, such as the work of McDermott (2002) and Galor and Mountford (2003), treat the emergence of international trade as being exogenous. ${ }^{2}$ On the other hand, the literature on endogenous tariff theory primarily uses static frameworks that ignore the dynamic aspects of trade and aggregate output. ${ }^{3}$

This research distinguishes itself from these previous articles by exploring the historical evolution of trade policy and economic growth. Analyzing political responses to the distributional effects of trade, the research finds that there is a prominent interaction between trade and growth, and emphasizes the role of trade liberalization in economic take-off.

The analysis is focused on the development of Western Europe since the mid-17th century, dividing it into three distinct epochs of trade policy. ${ }^{4}$ In the first epoch (1660-1830s), Western

\footnotetext{
${ }^{1}$ See, for example, Goodfriend and McDermott (1995), Galor and Weil (2000), Kogel and Prskawetz (2001), and Hansen and Prescott (2002).

${ }^{2}$ There are two other notable articles relevant to the present paper. McDermott (1999) endogenizes a country's openness by incorporating government motivation for mercantilistic protection against the inflow of foreign ideas. In contrast to the present article, McDermott does not study international trade in commodities and, hence, overlooks the substantial impact of grain inflow on the 19th-century European economy. Baldwin et al. (2001) develop a growth model in which exogenous reductions in the costs of trading goods (such as shipping costs and those associated with political barriers) promote industrial agglomeration in the North and thereby generate substantial income differences between the North and the South.

${ }^{3}$ See Mayer (1984), Magee, Brock and Young (1989), and Grossman and Helpman (1994), among others.

${ }^{4}$ This paper focuses on the international trade between Western Europe and the rest of the world, including Eastern Europe, and also focuses on restrictions on importing agricultural goods, rather than manufactured or other goods. As is well known, the grain trade was initially limited to the European continent because of underdeveloped transport systems. Amsterdam played a central role in determining grain prices in Europe in the 17th and 18th centuries (Glamann 1974, 457). In the 18th century, England and France shifted from intra-European trade to intercontinental trade (Kriedte 1983, Chap.3), and by the 1770s Atlantic trade became the engine of European economic growth
} 
European countries imposed severe restrictions on the import of grain, one of the main foodstuffs, thereby adversely affecting most people's living standards. The second epoch (1830s-1870s) was marked by a decisive shift toward free trade. The resulting influx of grain, especially from the New World and Russia, had substantial impacts on income distribution within societies. In response to the grain invasion, many of these nations went back to the protection of domestic agriculture, a competing sector. This political backlash characterizes the third epoch, which continues today. On top of these three historical stages, the theory developed in this paper predicts a second wave of globalization in the fourth and final stage. Thus, economies undergo two surges of liberalism with a stage of protectionism in between.

This paper accomplishes two worthy objectives. The primary objective is to analyze the nonmonotonic evolution of trade policy experienced by Western Europe, a region plausibly regarded to have been scarce in land and abundant in capital. ${ }^{5}$ This nonmonotonicity reflects qualitative changes in individuals' stances on trade liberalization in the process of economic development. The present paper provides a political-interest-based explanation for the determination of openness through an internal political process, rather than through diplomatic games played among trading countries. ${ }^{6}$ The secondary objective of the paper is to explain why some economies do not achieve trade liberalization and remain stagnant.

This paper develops a two-sector, two-good, overlapping-generations economy that uses two specific factors, land and capital, and one mobile factor, labor. ${ }^{7}$ The model features three elements that alter individuals' trade policy preferences in the growth process. The first element is the expansion of consumption bundles. While there are two marketable consumption goods, food and a manufactured good, the former is essential to low-income households for their survival. Hence,

(ibid., 125). For example, Carolina's rice exports increased fivefold between 1720 and 1740 (Nash 1992, 687).

${ }^{5}$ According to careful investigation by Rogowski (1989, pp. 154-158), as late as 1600, Northwestern Europe was abundant in capital and scarce in land, whereas Eastern Europe was abundant in land and scarce in capital. During the 16th century, the vast granaries of eastern Germany and Poland had achieved rapid growth, and by the first half of the 17th century, an annual average of 140,000 tons of grain flowed into North-Western Europe through the Danish Sound (De Vries 1976, 33). Although England was a net exporter of many types of grain in the first half of the 18th century, this was largely because of the bounty and was thus known as "a forced export" (Ormrod 2003, 216-217).

${ }^{6}$ The interest-based approach is adopted by Rogowski (1989), who applies the Stolper-Samuelson theorem to interpret class and rural/urban conflicts over trade policies in 19th-century European nations. However, he neither constructs a formal model nor discusses the determination of trade policy. The present article extends this line of research in order to analyze the dynamic interaction between trade policy and economic growth.

${ }^{7}$ While the model is an extension of Galor and Moav's (2004) one-sector, one-good growth model, their research accomplishes a different objective. They explore the effects of distributional policies on subsequent output growth in a closed economy, and suggest that the qualitative effects depend on the stage of development. 
their desired trade policy minimizes the unit cost of food. The second element is the expansion of income sources, in the sense that higher-income earners derive revenues from capital, in addition to their wage incomes. Because wages and interest rates are affected in opposite ways by trade liberalization, the level of savings is a key determinant of preferences over trade policy. The third and last element is the absence of land markets. This prevents the returns on land and capital from being equalized, which provides landowners with an incentive to support proagricultural trade policies.

The theory developed in this paper presents the following scenario for the evolution of a landscarce, capital-abundant economy. In the early stages of development, the economy operates under a closed system in which, because of the scarcity of land and the necessity of food, the agricultural sector absorbs a substantial part of the labor force. The resulting low wages (in terms of food) prevent the landless poor from purchasing the nonessential manufactured good, and their poverty sustains the economic dominance of landlords. In contrast, opening up to international trade breaks this class structure by placing egalitarian pressure on the income distribution. That is, food consumption by the poor is enhanced while landlords' rents are reduced. These two egalitarian forces of globalization - the rise of the working class and the fall of the landed elite - are a prime incentive for landlords to prefer autarky. Therefore, the initial development process entails a political struggle between landed and landless interests. Provided that the former group wields political power, the economy adopts protectionist policies.

Although free trade raises landlords' revenues derived from industrial capital, this positive effect is not dominant in the initial stages when industrial capital is a minor asset in their portfolios. However, in later stages, capital accumulation, in conjunction with a limited supply of land, gradually raises the relative importance of capital for landlords and thereby makes industrial specialization profitable for them. Through this mechanism, an epochal policy switch to free trade takes place and dissolves class conflict between landlords and workers. The theory of this paper also raises the possibility that the economy remains closed because of the supply of land: given a certain amount of land, landlords adhere to protectionist policies because agriculture is their main income source. For this reason, an abundance of land tends to prevent or delay the industrialization process under free trade.

As the economy develops under free trade, further specialization in manufacturing raises wage 
rates (in terms of food), and this eases the food constraint that binds the working class. This improvement in living standards permits landless workers to consume the manufactured good as well as food. In these circumstances, they may be less supportive of liberal (i.e. proindustrial and antiagricultural) policies, because industrial specialization raises the relative price of the manufactured good. Noting that the degree of worker opposition to liberalization hinges on the wage elasticity with respect to the trade policy that is pursued, the theory predicts that the elasticity depends on the supply of land. Consistent with the historical experience of Western Europe, it is shown that the protection of agriculture emerges in moderately land-scarce countries (such as Germany and France), whereas severely land-scarce countries (such as the United Kingdom) tend to maintain liberalism. Hence, as long as rising wages lead to an extension of the franchise, the political participation of the landless class causes a resurgence in protectionism.

Unless the political backlash is overwhelming, capital accumulation continues to boost output and real wages, which ultimately enables everyone to generate savings. Because trade liberalization leads to a rise in interest rates, all individuals support proindustrial liberal policies in later stages of development when their savings are sufficient and when owning land is not particularly lucrative. This eventual shift to liberalism should be interpreted as a prediction of the type of trade policy to be pursued in a forthcoming stage of development. This is because most current developed countries still adhere to agricultural protection. In other words, it is difficult to introduce trade liberalization without promoting political conflict. This is because reaching such a high stage of development requires highly productive technology in the industrial sector.

It is worth discussing the empirical relevance of the model developed in this paper. The model can be viewed as a ramification of the Heckscher-Ohlin model, in the sense that it enables one to explore the effect of a relative commodity price on factor prices. While many empirical papers based on postwar data find that the Heckscher-Ohlin model performs poorly (see, e.g., Leontief 1953 and Trefler 1995), O'Rourke et al. (1996) find that it performs reasonably well in the late 19th century, which is the period on which this paper focuses. Their results indicate that the factor-price convergence between the Old and New Worlds in this period was driven by commodityprice convergence. This evidence supports the factor-price-equalization theorem derived from the Heckscher-Ohlin model.

The rest of this paper is organized as follows. Section 2 presents historical evidence on European 
trade policy and economic development. Section 3 describes the basic structure of the model. Section 4 derives the market equilibrium and the political equilibrium in each period. Section 5, the main part of the paper, demonstrates the coevolution of trade policy and output, as experienced by industrial economies, and also demonstrates the possibility of a poverty trap arising because of a failure to liberalize trade. Section 6 concludes the discussion and proposes possible extensions to the research. Proofs of technical results are in the Appendix.

\section{Historical Evidence}

This section presents the historical evidence on Western European trade policy and economic development that supports the central argument of the paper. ${ }^{8}$ As mentioned in the introduction, this paper considers trade in goods between Western Europe and other regions. The investigation dwells on the role of trade policy, rather than transportation costs, in determining a country's openness. Moreover, in the context of the paper, trade protection means restrictions on the imports of agricultural goods, rather than of manufactured or other goods. The following three epochs construct a broad picture of the history of Western European trade policy over the last three centuries.

\subsection{The Age of Protectionism, 1660-1830s}

Protectionism was the prevailing doctrine in Europe during this period, and the import of grain was severely constrained by national laws, the most well known and important of which were the British Corn Laws, which were in force until $1846 .{ }^{9}$ According to Bairoch (1989, 7-8), "It should be noted that 'Corn Laws' were a quasi-permanent feature of tariff history in most European countries. They had always aimed at a precarious balance between protecting local agriculture and preventing the price of bread rising too steeply." For instance, Burke's Act of 1773 fixed the threshold price for the domestic market, above which wheat could be imported, at 44 shillings per quarter, and was later raised to 80 shillings per quarter by the law of 1815 (ibid., 8). ${ }^{10}$ Likewise, in France,

\footnotetext{
${ }^{8}$ I thank Daniel Mejia and Jeffrey G. Williamson for supplying Figure 1 and Figures 2(a)-2(b), respectively.

${ }^{9}$ The term 'corn' did not merely mean American corn or maize; rather, the term meant grains such as wheat, oats, rye, barley, malt, peas, beans, and maize (Barnes 1965, 7). Although the British Corn Laws existed before 1660, it was not until 1660 that the government restricted the import of grain and encouraged grain exports (Barnes 1965, 8 and Glamann 1974, 465). Unlike the UK, most European countries were protectionist at least until the early 19th century (Bairoch 1989, 6-7). This paper conventionally sets 1660 as the initial period of analysis.

${ }^{10} \mathrm{~A}$ quarter of wheat was $217.7 \mathrm{~kg}$.
} 
landowners succeeded in introducing a sliding scale tariff to protect cereals between 1815 and 1845 (Fohlen 1973, 30). Before the 19th century, protectionist policies against foreign grain generally restricted intracontinental trade, rather than intercontinental trade. ${ }^{11}$

The absence of grain imports kept European economies under agricultural-land constraints. Using British data from between 1565 and 1936, O'Rourke and Williamson (2000) found a clear relationship between commodity and factor prices and endowments for the pre-1828 period. They also noted that this relationship broke down after 1828, rather than after the 1490s, which was the era of the Voyages of Discovery. Based on this finding, they suggest that for the period before 1828, the closed-economy model is superior to the open-economy model, which is better for the period after 1828.

Some evidence indicates that the living standards of the working class did not improve in this epoch; rather, they deteriorated. For instance, Allen (2001, 427-429) reports that indicators of the welfare of laborers in many European cities trended downward or were stable between 1500 and 1800; they suggest that incomes were just enough to cover rents and necessities. Similarly, Hoffmann et al. (2002) found that for the period between 1500 and about 1800, both unskilled labor and luxury goods generally became cheaper relative to staple foods (grains and bread) in major European regions (Table 2 and Figure 1, 331-333). They also found that working people spent a greater share of their budgets on grain than did upper class people in England and Wales, France, and the Netherlands (Table 1, 326-327). ${ }^{12}$ Consistently with this evidence, the growth model developed in this paper predicts that the relative price of food rises under autarky.

\footnotetext{
${ }^{11}$ It appears that intercontinental trade in grain was not the primary concern of pre-19th century policy makers because of substantial freight costs. Some historians, such as Irwin (2001) and Taylor (2002), argue that it was underdeveloped shipping technology, rather than protectionist policies, that constrained intercontinental trade from the 16th century to the 18th century. While Europe engaged in trade with other continents, such as the New World, Asia, and India following the Voyages of Discovery, most traded commodities between 1500 and 1800 were noncompeting luxury goods, which were of high value relative to their transport costs. Examples include pepper, other spices, cotton textiles, tea and coffee from Asia, and sugar, tobacco and silver from the Americas (Findlay and O'Rourke 2001, 7-10 and Table 1). Because luxury goods were beyond the budget of low-income groups, intercontinental trade was of little relevance to living standards, except those of elite Europeans (Irwin 2001 and Williamson 2002c, 16).

${ }^{12}$ In England and Wales in 1688, the bottom $40 \%$ of income earners spent about $35 \%$ of their incomes on bread and other grain, whereas the top $5 \%$ spent only $4.2 \%$ on these goods. In France, rural workers spent $30.8 \%$ of their incomes on bread and other grain in 1763, whereas middle and upper class people spent only $1.7 \%$ on these items in 1788. This implies that the relative price of grain was more important for the living standards of poorer people.
} 


\subsection{The First Period of Globalization, 1830s-1870s}

The triumph of liberalism was symbolized by Britain's repeal of the Corn Laws in $1846 .{ }^{13}$ Williamson (1990, Table 1, 128) estimates that the ad valorem tariff equivalent on grain in Britain fell from about $71 \%$ to about $22 \%$ between 1815 and 1845 - a significant step toward free trade. Britain's liberal ideas spread throughout most of Europe, especially after 1860, when Britain and France agreed on the Anglo-French treaty that incorporated the most-favored-nation clause (Bairoch 1989, 40 and Minchinton 1973, 100). ${ }^{14}$ Wheat continually came into Europe from Australia, Argentina, India, the American mid-west, and Canada, and the value of wheat exports from America increased 20fold between 1850 and 1915 (Woodruff, 1973, 660). ${ }^{15}$ In Germany, Belgium, and France, imports of grain accounted for $3 \%$ of domestic production in the period $1862-1866$ and reached $20 \%$ in the 1876-1880 period (Bairoch 1989, 47).

The dismantling of agricultural protection and the associated inflow of grain on an enormous scale brought about two major changes in European economies. The first was that within-country wealth inequalities were reduced. O'Rourke and Williamson (2003) report that in Northwestern Europe, the wage-land rent ratio had been rising in the 18th century and began to fall in the 19th century. The second was the specialization in capital-intensive goods, which shifted workers from agricultural to industrial sectors. Britain's agricultural workforce began to decline after 1850. This decline was tied to the introduction of new technologies as well as to massive increases in agricultural imports (Pomeranz 2000, 287). These two dramatic changes show that trade liberalization and the accompanying grain inflows caused a structural breakdown; they transformed Western Europe from an autarkic economy to an open economy and led to the elimination of resource constraints.

Meanwhile, political power was wielded by the landed elite in most European nations. For example, Aydelotte $(1967,51)$ reports that the share of the British aristocracy and gentry in the

\footnotetext{
${ }^{13} \mathrm{As}$ is conventional, this article defines the $1830 \mathrm{~s}$ as the first period of globalization. While the triumph of liberalism was symbolized by Britain's repeal of the Corn Laws in 1846, the onset of liberalism dates back to the early 1820s. The progress of British liberalization was gradual but steady during the subsequent period of policy reforms. In 1822 , the nation reduced the threshold price (referred to in Section 2.1) to 70 shillings per quarter (Bairoch 1989, 9).

14 "The most-favored-nation clause is a formula by which each of the two signatories to a treaty agrees to grant the other any advantage, favor, or privilege with regard to trade or navigation that it granted at the time of signing, or that it would grant in the future, to any other nation" (Bairoch 1989, 38-39). According to Minchinton (1973, 100), the abolition of grain duties was conducted by the Zollverein in 1853, by Britain in 1860, by France and the Netherlands in 1862, by Italy in 1870, and by Belgium in 1871.

${ }^{15}$ The increase from the late 19th century onwards occurred mainly because of reductions in transportation costs and advances in the technology used for wheat production, rather than because of liberal trade policy. This is because agricultural protection prevailed during this period in Western Europe.
} 
House of Commons was roughly $80 \%$ in 1846 , the year in which the Corn Laws were repealed. Moreover, as depicted in Figure 1, before the 1870s, the franchise was limited to a small segment of the population in the main parts of Europe, except France. Because landlords were in the richest class during this period and because restriction of the franchise was based on incomes, arguably the most common form of political regime in Europe was one in which the landed elite dominated. Hence, many of the landlords' preferences were presumably reflected in the trade policies adopted, and trade liberalization would not have been achieved without their broad support.

One of the potential forces behind the policy switch to free trade was, as mentioned in the introduction, the rising relative importance of industrial capital in landlords' portfolios. ${ }^{16}$ This hypothesis is consistent with the empirical work of Schonhardt-Bailey (1991), who focuses on the case of Britain in the first half of the 19th century. She has documented the increased diversification of the asset portfolios of British landowners and found that Members of Parliament representing more diversified constituencies were more likely to vote for free trade. In addition, Thompson (1994, 166-167) has documented the aristocracy's decreasing dependence on agricultural incomes in the 19th century in England. ${ }^{17}$

\subsection{Political Backlash, 1870s Onwards}

As shown by Minchinton $(1973,100)$, the retreat from free trade occurred in much of continental Europe in the late 19th century (in Italy in 1878, in Germany in 1879, in France in 1881, in Bulgaria in 1883, in Switzerland in 1884, in Rumania in 1886, in Belgium and Sweden in 1887, and in Austria-Hungary, Spain, Portugal, and Russia in the same decade). The impact of cheap New World and Russian grain became evident in European markets by the late 1870s and 1880s, as is apparent from the 50\% decline in real British land rents between 1870 and 1913 (Findlay and O'Rourke 2001, 35). The general response to this 'grain invasion' was to protect domestic agricultural sectors to a greater extent than industrial sectors.

\footnotetext{
${ }^{16}$ According to O'Rourke's (2000) recent review of British trade policy, economic historians suggested two other major reasons for the repeal of the Corn Laws. Kindleberger (1975) suggests that economic ideas convinced the voters of the efficiency of free trade. By contrast, Irwin (1989) argues that a gradual loss of faith in Malthusian and Ricardian theories prompted the prime minister Robert Peel to convert to liberalism. By contrast, this paper focuses on another potential source of trade liberalization.

${ }^{17}$ An empirical study by Scheve and Slaughter (2001) provides indirect evidence for the view that real-estate ownership affects trade-policy preferences. Based on recent individual-level survey data for the United States, they confirm that trade barriers were more likely to be supported by individuals who owned houses in counties where industries with comparative disadvantages were concentrated. Home ownership in their study plays a similar role to that played by the ownership of agricultural land in this paper.
} 
Table 1 Import Tariff Levels in 1913 (percentage of value)

\begin{tabular}{lcc}
\hline Country & Manufacturers & Wheat \\
\hline Austria-Hungary & 20 & 35 \\
Belgium & 9 & 0 \\
Denmark & - & 0 \\
Finland & 28 & 0 \\
France & 21 & 38 \\
Germany & 13 & 36 \\
Italy & 20 & 40 \\
Netherlands & - & 0 \\
Norway & - & 4 \\
Portugal & - & prohibitive \\
Spain & 34 & 43 \\
Sweden & 25 & 28 \\
Switzerland & 8 & 2 \\
United Kingdom & 0 & 0 \\
Continental Europe & 19 & 25 \\
\hline
\end{tabular}

Source. Bairoch (1989, Table 9, 76 and Table 16, 139).

Evidence of this series of political backlashes can be observed in time-series and cross-sectional data. The time-series data illustrated in Figures 2(a)-2(b) show that several geographically large countries, such as Austria-Hungary, France, Germany, and Italy, were mainly raising tariffs during this epoch, whereas the United Kingdom, a geographically small country, was not. ${ }^{18}$ In fact, the United Kingdom maintained free trade until 1932 (Bairoch 1989, Section VI). Turning to the crosssectional data, the bottom row of Table 1 shows that continental Europe was on average more protectionist against imports of wheat than against imports of manufactured goods. This was the case in Austria-Hungary, France, Germany, Italy, Spain, Sweden, and, to some extent, Portugal. The United Kingdom, in sharp contrast, displayed considerable and widespread liberalism. The asymmetry in European political responses was initially identified by Kindleberger $(1951,33)$. He argues that "the response of Germany, France, and Italy to the decline in the world price of wheat was to impose tariffs in an attempt to maintain the relative price of wheat and to protect grain

\footnotetext{
${ }^{18}$ Between the 1870 s and the 1890 s, the average tariff rate increased from $4.4 \%$ to $10.1 \%$ in France, and from $3.8 \%$ to $9.1 \%$ in Germany (Blattman et al. 2002, 5).
} 
Table 2 Net Exports, 1876-1880 and 1913: Actual Prices (\$ million)

\begin{tabular}{lcccc}
\hline & \multicolumn{2}{c}{$1876-1880$} & \multicolumn{2}{c}{1913} \\
Region & Primary Products & Manufactures & Primary Products & Manufactures \\
\hline United Kingdom & -1245 & 640 & -1836 & 1150 \\
NW Europe & -960 & 630 & -2830 & 1523 \\
Other Europe & 235 & -120 & 104 & -555 \\
USA and Canada & 270 & -90 & 559 & -157 \\
Oceania & & & 326 & -361 \\
Latin America & $838^{*}$ & $-1250^{*}$ & 936 & -828 \\
Africa & & & 373 & -425 \\
Asia & & & 843 & -786 \\
\hline
\end{tabular}

Sources. Findlay and O'Rourke (2001, Table 4), originally from Lamartine Yates (1959, Tables A.19-A.22).

*Includes Oceania, Latin America, Africa, and Asia.

producers," whereas "Like Britain, the Netherlands, and Belgium, Denmark did not impose a tariff on wheat." A plausible conjecture based on the time-series and cross-sectional data is that between the 1870s and 1913, core European countries generally became protectionist against foreign trade and that there was more protection of agriculture than industry.

The resurgence of protectionism was not sufficiently powerful to cause a return to the economic isolation that prevailed before the first period of globalization (Williamson 2002a, 4). As shown in Table 2, despite their proagricultural policies, Northwestern Europe and the United Kingdom remained net importers of primary products and net exporters of manufactured goods at the beginning and at the end of this epoch, whereas the opposite is the case for all the other regions.

Two empirical observations are consistent with this article's view that the retreat into protectionism was provoked in part by expansion of the working classes. ${ }^{19}$ First, Figure 1 clearly illustrates that many European nations experienced a dramatic extension of the franchise around the end of the 19th century, which implies that the middle class was gaining political influence. Second, in a study that quantifies the potential impact of cheap grain, O'Rourke (1997) found that the welfare effects of the grain invasion on workers differed between European nations. As does the present paper, the study of O'Rourke examines two opposing effects of free trade on the real

\footnotetext{
${ }^{19}$ Because there are only two income classes in the economy analyzed below, in the context of the model, the term 'workers' includes small-scale capitalists, whose major source of income is wages.
} 
wage - effects incorporated in the standard rural-urban specific-factors model: the decline in the value of the wage in terms of manufactured goods and the rise in the value of the wage in terms of food. By utilizing a computable general equilibrium model that has parameters based on empirical data, O'Rourke found that the former negative effect outweighed the latter positive effect in France, which had a large agricultural sector, whereas the opposite was true for Britain, which had a small agricultural sector (ibid., 792). By combining these two results, this article asserts that within Western Europe, differences in the sizes of agricultural sectors may have been associated with diverging political responses to the grain invasion.

The protection of agricultural sectors continues, as was demonstrated at the World Trade Organization meeting in Mexico in 2003. Coppel and Durand (1999, Figure 1, 20) found evidence of stationary trends in producer support estimates (PSEs) in OECD countries' agricultural sectors between 1986 and 1998. During this period, the PSEs remained at about $40 \%$ in the European Union, at about $20 \%$ in the United States, and at about $60 \%$ in Japan; these levels are well above those prevailing in Australia and New Zealand (ibid., 6). In contrast, trade liberalization in manufactured goods has been successful. Findlay and O'Rourke (2001, Table 5, 67) have documented the declining trend in average tariffs on manufactured goods for 27 major countries between 1913 and 1998. Intercontinental price gaps between 1950 and 2000 were cut by $76 \%$, of which no less than $74 \%$ can be attributed to trade liberalization (Lindert and Williamson 2001, Table 1). These reports suggest that manufacturing sectors contribute most to trade liberalization.

\subsection{Summary}

This historical evidence teaches one that a country's trade policy can vary over time in accordance with its stage of economic development. A country may even experience an ebb and flow in its trade policies during the growth process, as is evident from the political backlashes that occurred in 19th-century continental Europe. Another lesson is that the opening of an economy to international trade paves the way to modern growth by alleviating the economy's resource constraints. Hence, international trade appears to have a considerable influence on economic growth and living standards. These important points are confirmed by the theoretical analysis that follows. 


\section{The Model}

Consider a two-sector overlapping-generations economy operating in a two-good world over an infinite discrete-time horizon. The three factors of production are land, capital, and mobile labor. An agricultural good is produced in one sector by employing land and labor, and a manufactured good is produced in the other sector by using physical capital and labor. Economic growth is driven by capital accumulation, which is affected by trade policies but not by other potential forces such as population growth, technological progress, and the expansion of land supply. ${ }^{20}$

The economy may take part in international trade in final goods without affecting world markets. Whereas the world economy does not impose restrictions on trade, the economy under study may become protectionist. In this event, the government would only use tariffs for protection, and tariff levels would be determined endogenously through the internal political process. Tariff revenues are not rebated to individuals but are spent on consumption by the government.

\subsection{The Production of Final Goods}

The production environments are perfectly competitive, and households rent land, capital, and labor to producers. Independently of political decisions about trade policies, all agents in the markets act as price takers who can perfectly predict the future course of the economy. Labor is perfectly mobile between sectors, and inputs are, unlike final goods, immobile between countries.

\subsubsection{The Agricultural Sector}

This sector produces the agricultural good, which is both perishable and indispensable for survival. Production is based on CES technology. Let $X_{t}$ and $L_{t}^{A}$ denote the quantities of land and labor employed by this sector in period $t$. The output of the agricultural good produced in period $t, y_{t}^{A}$, is then

$$
y_{t}^{A}=F\left(X_{t}, L_{t}\right)=A\left[a X_{t}^{\delta}+(1-a) L_{t}^{\delta}\right]^{1 / \delta},
$$

with $A>0, a \in(0,1)$ and $\delta \in(-\infty, 0)$. The parameter restriction imposed on $\delta$ means that one of the Inada conditions cannot be satisfied: that is, the marginal productivity of each input does not remain finite as the corresponding input approaches zero. As shown subsequently, this property

\footnotetext{
${ }^{20}$ Letting physical capital affect agricultural production would not alter the basic results, provided that the accumulation of aggregate capital caused labor to flow to the manufacturing sector.
} 
permits complete specialization in manufacturing in the later stages of economic development. ${ }^{21}$ Producers in period $t$ maximize their profits given $p_{t}$, the price of the agricultural good, $\pi_{t}$, the rental price per unit of land, and $w_{t}^{A}$, the wage per unit of labor in period $t$. For convenience, the manufactured good is taken as the numeraire. This standard optimization problem is solved by maximizing $p_{t} y_{t}^{A}-\pi_{t} X_{t}-w_{t}^{A} L_{t}$ with respect to $X_{t}$ and $L_{t}$. Substituting a fixed land supply, $X>0$, into the resulting inverse demand functions yields

$$
\begin{aligned}
& \pi_{t}=p_{t} F_{X}\left(X, L_{t}\right) ; \\
& w_{t}^{A}=p_{t} F_{L}\left(X, L_{t}\right),
\end{aligned}
$$

where $F_{i}$ denotes the partial derivative of the function $F$ with respect to argument $i$. In what follows, this notation applies to all functions.

\subsubsection{The Manufacturing Sector}

This sector produces the manufactured good, which can be consumed or stored, based on CobbDouglas technology. Let $K_{t}$ be the aggregate quantity of capital employed by this sector in period t. In addition, let the working population in each period be normalized to unity for notational simplicity. Because there is no unemployment in these competitive environments, the output of the manufactured good produced in period $t, y_{t}^{M}$, is

$$
y_{t}^{M}=M K_{t}^{\alpha}\left(1-L_{t}\right)^{1-\alpha}=M k_{t}^{\alpha}\left(1-L_{t}\right)
$$

where $\alpha \in(0,1), k_{t} \equiv K_{t} /\left(1-L_{t}\right)$, and $M>0$ denotes the level of technology. Note that $k_{t}$ is the ratio of capital to labor employed in the manufacturing sector, not the capital-labor ratio for the aggregate economy. As in the agricultural sector, producers in period $t$ maximize their profits given $w_{t}$, the market wage per unit of labor, and $r_{t}$, the rental price per unit of physical capital, in period $t$. The market price of the manufactured good is normalized to unity. Therefore, the inverse demand functions are

$$
\begin{aligned}
& r_{t}=\alpha M k_{t}^{\alpha-1} \equiv r\left(k_{t}\right) ; \\
& w_{t}=(1-\alpha) M k_{t}^{\alpha} \equiv w\left(k_{t}\right),
\end{aligned}
$$

where the rate of return on labor, $w_{t}$, increases with physical capital. For simplicity, it is assumed that physical capital depreciates completely after being used.

\footnotetext{
${ }^{21}$ An economy that incorporates Cobb-Douglas technology would not completely specialize in manufacturing even at such a stage of development. In this case, the central argument of the paper could be maintained, but simplicity of exposition would be lost.
} 


\subsubsection{The Allocation of Labor}

Because of perfect labor mobility, wages are equalized across sectors producing positive amounts of output, as follows.

$$
w\left(K_{t} /\left(1-L_{t}\right)\right)=p_{t} F_{L}\left(X, L_{t}\right)
$$

This implies that the industrial sector is active and that $L_{t}<1$ as long as the economy has a positive amount of physical capital. Because of the bounded marginal productivity of agricultural labor, by contrast, agricultural production may be zero depending on the amount of physical capital relative to the amount of land. In other words, there exists a price level, $p_{t}^{\min } \equiv w\left(K_{t}\right) / F_{L}(X, 0)$, below which the industrial wage remains above the agricultural wage and, hence, no one works in agriculture. It follows that the employment of labor in agriculture is described by a single-valued function such that, for a given pair $\left(K_{t}, p_{t}\right) \gg 0$,

$$
L\left(K_{t}, p_{t}\right)=L_{t} \begin{cases}=0 & \text { if } \quad p_{t} \leq p_{t}^{\min } \\ \in(0,1) & \text { if } \quad p_{t}>p_{t}^{\min }\end{cases}
$$

where $L_{K}(\cdot)<0$ and $L_{p}(\cdot)>0$ in the second case (i.e., there is incomplete specialization). The first property implies that a rise in the industrial capital-labor ratio raises the wage rate in industry and thus causes labor to flow from agriculture. The second property implies that a rise in the relative price increases the marginal productivity of labor and thereby labor demand in agriculture. In what follows, this paper assumes that the economy has a positive amount of physical capital, so that the market wage rate equals $w_{t}$ in every period.

\subsection{Individuals}

A new generation, consisting of a continuum of individuals, is born at the beginning of every period and lives for two periods. Hence, there are two generations in society at each point in time. The population size of each generation is normalized to unity. Individuals may differ in their initial endowments, but they are homogeneous in all other respects. An individual born in period $t$ is referred to as a member $i \in[0,1]$ of generation $t$.

\subsubsection{The Environment}

In the first period of life (youth), a member $i$ of generation $t$ does not work and consumes the agricultural and manufactured good provided by his or her single parent. In addition, he or she 
may receive a transfer (in the form of the manufactured good) from his or her parent, $b_{t}^{i} \geq 0$, and keep it for savings. In the second period (adulthood), the individual has a single child and acquires one unit of labor. By supplying this labor inelastically, the individual receives wage income of $w_{t+1}$, which is the market wage rate at time $t+1$ in terms of the manufactured good. Individuals who have savings earn interest, and those who own land are paid interest by producers. To keep the model tractable, suppose that there is no market for land in this economy because land is held by previous generations and inherited by the next generation within dynasties. To summarize, a member $i$ of generation $t$ has a second-period income of

$$
I_{t+1}^{i}=w_{t+1}+r_{t+1} b_{t}^{i}+\pi_{t+1} x^{i}
$$

where $r_{t+1}$ is the net return on savings under the assumption of complete capital depreciation, and $x^{i}$ denotes the amount of land owned by the individual.

\subsubsection{Consumption}

As mentioned in the introduction, this paper considers an extreme case of Engel's Law. In other words, individuals spend their incomes exclusively on the agricultural good, which is thought of as staple food, up to a saturation level of $\hat{c}>0$. It follows that the household food consumption of a member $i$ of generation $t$, is

$$
\begin{array}{ll}
c_{t+1}^{i}=I_{t+1}^{i} / p_{t+1} & \text { if } I_{t+1}^{i} \leq p_{t+1} \hat{c} \\
c_{t+1}^{i}=\hat{c} & \text { if } I_{t+1}^{i}>p_{t+1} \hat{c},
\end{array}
$$

where the first expression applies when the food constraint is binding. Any remaining income is allocated between $m_{t+1}^{i}$, which represents household consumption of the manufactured good, and $b_{t+1}^{i}$, which represents a transfer of income to the child in the form of the manufactured good. The allocation is chosen to maximize utility, which is given by

$$
u_{t}^{i}=(1-\beta) \ln m_{t+1}^{i}+\beta \ln \left(\bar{\theta}+b_{t+1}^{i}\right),
$$

where $\beta \in(0,1)$ and $\bar{\theta}>0$. The utility function implies that bequeathing is motivated by the 'joy of giving'. ${ }^{22}$ The budget constraint in this case is given by

$$
z_{t+1}^{i} \equiv I_{t+1}^{i}-p_{t+1} \hat{c} \geq m_{t+1}^{i}+b_{t+1}^{i},
$$

\footnotetext{
${ }^{22}$ For simplicity, it is assumed that no one dies regardless of the amount of food consumption. Incorporating death makes the model more realistic but does not affect the paper's qualitative results. The qualitative results of the paper would survive the incorporation of a more realistic utility function, such as $\beta_{1} \ln \left(c_{t+1}-\hat{c}\right)+\beta_{2} \ln m_{t+1}+\left(1-\beta_{1}-\right.$ $\left.\beta_{2}\right) \ln b_{t+1}$, provided that $\beta_{1}$, the weight associated with excess food consumption, is sufficiently small.
} 
where $z_{t+1}^{i}$ can be interpreted as net income, given that initial food expenditures of $p_{t+1} \hat{c}$ are required. It follows that

$$
\begin{aligned}
& m_{t+1}^{i}= \begin{cases}z_{t+1}^{i} & \text { if } 0 \leq z_{t+1}^{i}<\theta ; \\
(1-\beta)\left(z_{t+1}^{i}+\bar{\theta}\right) & \text { if } z_{t+1}^{i} \geq \theta ;\end{cases} \\
& b_{t+1}^{i}= \begin{cases}0 & \text { if } z_{t+1}^{i}<\theta ; \\
\beta\left(z_{t+1}^{i}-\theta\right) & \text { if } z_{t+1}^{i} \geq \theta\end{cases}
\end{aligned}
$$

where $\theta \equiv \bar{\theta}(1-\beta) / \beta>0$. Because of the inclusion of $\bar{\theta}>0$ in the utility function (9), low-income households prefer consuming the manufactured good to leaving it to their offspring.

\subsubsection{Group Structures}

In period 0, there are two income groups, $R$ (Rich) and $P$ (Poor), which respectively comprise the fixed fractions $\lambda \in(0,1)$ and $1-\lambda$ of adult individuals. Land and capital are distributed equally within group $R$, whereas group $P$ is proletarian. Because there is no within-group heterogeneity, descendants can be fully identified by $i=P, R$ in each period.

Linear homogeneity of the production functions implies that the allocation of aggregate income is given by

$$
y_{t}=\lambda I_{t}^{R}+(1-\lambda) I_{t}^{P}
$$

From (7) and (10), it follows that

$$
I_{t}^{R}>I_{t}^{P} \quad \text { and } \quad b_{t}^{R} \geq b_{t}^{P} \quad \text { for all } t \geq 0
$$

This is satisfied with equality only if $b_{t}^{R}=b_{t}^{P}=0$. The strict inequality in the expression for income, $I_{t}^{R}>I_{t}^{P}$, results from permanent inequality in the ownership of land and the monotonicity of the returns on savings. Equation (12) implies that the initial ranking of wealth among individuals persists into the future. This between-group inequality is plausible, given the historical evidence, and enables an examination of the effects of international trade on individuals whose living standards differ.

\section{Equilibrium}

This section analyzes the determination of the competitive market equilibrium in each period. 


\subsection{Aggregate Capital and Output}

In the absence of opportunities for international lending and borrowing, aggregate savings form aggregate capital in the subsequent period. Hence,

$$
K_{t+1}=\lambda b_{t}^{R}+(1-\lambda) b_{t}^{P} \equiv B_{t}
$$

where $B_{t}$ denotes aggregate transfers in period $t$. Note that the savings of group $R$ are indispensable for the formation of physical capital.

Given (1), (3) and (13), aggregate output is expressed as

$$
y_{t+1}=p_{t+1} F\left(X, L_{t+1}\right)+M B_{t}^{\alpha}\left(1-L_{t+1}\right)^{1-\alpha} \equiv y\left(B_{t}, p_{t+1}\right)
$$

where $L_{t+1}=\arg \max y_{t+1}$ because of perfect labor mobility. It follows that $y_{B}(\cdot)=R_{t+1}>0$ provided that the manufacturing sector is operative in period $t+1$. In addition, $y_{p}(\cdot)=y_{t+1}^{A} \geq 0$, which implies that a rise in the relative price of the agricultural good increases its value.

Given (6), the industrial capital-labor ratio is

$$
k_{t+1}=\frac{B_{t}}{1-L\left(B_{t}, p_{t+1}\right)} \equiv k\left(B_{t}, p_{t+1}\right)>0,
$$

where $\left(B_{t}, p_{t+1}\right) \gg 0$. Wage equalization (5) implies that $k\left(B_{t}, p_{t+1}\right)$ is a single-valued function such that

$$
k_{B}(\cdot)>0 ; \quad \lim _{B_{t} \rightarrow \infty} k(\cdot)=\infty ; \quad k_{p}(\cdot) \geq 0,
$$

where the last inequality is strict because of incomplete specialization in period $t+1$. The economic intuition behind these properties is worth emphasizing. First, a rise in aggregate transfers, $B_{t}$,

increases the capital-labor ratio in industry $k_{t+1}$ by raising aggregate savings. Second, $k_{p}(\cdot)$ is positive because a rise in the relative price of food improves the marginal productivity of agricultural labor and thereby attracts more workers to the agricultural sector.

\subsection{The Political System}

Let $v_{t}^{i}$ be the indirect utility of a member $i$ of generation $t$. It follows from (8) and (10) that

$$
v_{t}^{i}= \begin{cases}I_{t+1}^{i} / p_{t+1} & \text { if } z_{t+1}^{i}<0 \\ (1-\beta) \ln z_{t+1}^{i} & \text { if } 0 \leq z_{t+1}^{i}<\theta ; \\ \ln \left(z_{t+1}^{i}+\bar{\theta}\right)+\varepsilon & \text { if } z_{t+1}^{i} \geq \theta\end{cases}
$$


where $\varepsilon \equiv(1-\beta) \ln (1-\beta)+\beta \ln \beta$. In (7), income, $I_{t+1}^{i}$, includes the factor prices $w_{t+1}, r_{t+1}$, and $\pi_{t+1}$, which are, as explained in Section 3.1, completely determined by the capital-labor ratio, $k_{t+1}$, and the relative price, $p_{t+1}$. Hence, given (15), and noting that $b_{t}^{R}=\left[B_{t}-(1-\lambda) b_{t}^{P}\right] / \lambda$, it follows that

$$
\begin{aligned}
& I_{t+1}^{i}=I\left(k_{t+1}, b_{t}^{i}, p_{t+1}, x^{i}\right) \equiv I^{i}\left(B_{t}, b_{t}^{P}, p_{t+1}\right) \\
& z_{t+1}^{i}=I^{i}\left(B_{t}, b_{t}^{P}, p_{t+1}\right)-p_{t+1} \hat{c} \equiv z^{i}\left(B_{t}, b_{t}^{P}, p_{t+1}\right)
\end{aligned}
$$

Suppose that the economy has a comparative advantage in manufacturing in international markets, in which the relative price of food is constant at $p^{w}>0$. Then, the domestic price falls to a level that is on the interval $\left[p^{w}, p_{t+1}^{c}\right] \equiv \mathbf{p}_{t+1}$, depending on the tariff level levied by the home country. It follows that the preferred price for a member $i$ of generation $t$ (working in period $t+1)$ is

$$
p_{t+1}^{i}=\left\{\begin{array}{ll}
\arg \max \left(I_{t+1}^{i} / p_{t+1}\right) & \text { if } z_{t+1}^{i} \leq 0, \forall p_{t+1} \in \mathbf{p}_{t+1} \\
\arg \max z_{t+1}^{i} & \text { otherwise }
\end{array}\right\} \equiv p^{i}\left(B_{t}, b_{t}^{P}\right)
$$

where $I_{t+1}^{i}$ and $z_{t+1}^{i}$ are given by (18). This implies that the individual's preferred (optimal) trade policy depends on his or her living standards. This is because the individual's consumption bundle is larger the higher is individual income.

Consider a political system in which only young individuals (with perfect foresight) whose living standards exceed some threshold have the franchise. Suppose also that majority voting determines the trade policy that is implemented when they are adults. Because young individuals do not supply labor, their living standards are completely dependent on their respective parents' incomes. For simplicity, suppose that a young individual has voting rights if and only if his or her parent earns enough to purchase the manufactured good as well as food. It follows from (12) that group $R$ has voting rights as long as the industrial sector is in operation.

This framework implies that one of two political regimes emerges during the process of economic development. Under Regime I, the food constraint is binding for group $P$ and, thus, political decisions are made by group $R$. Under Regime II, sufficient capital has accumulated to raise the income level of group $P$, and this enables their political participation. Formally,

$$
p_{t+1}= \begin{cases}p_{t+1}^{R} & \text { if } z_{t}^{P} \leq 0 \text { (Regime I) } \\ p_{t+1}^{P} & \text { otherwise (Regime II) }\end{cases}
$$




\subsection{The Dynamical System}

It follows from (10), (11), and (12) that the evolution of aggregate transfers and of intergenerational transfers within group $P$ is given by

$$
\begin{aligned}
B_{t+1} & =\left\{\begin{array}{ll}
\beta \max \left[y_{t+1}-(1-\lambda) I_{t+1}^{P}-\lambda\left(p_{t+1} \hat{c}+\theta\right), 0\right] & \text { if } z_{t+1}^{P} \leq \theta \\
\beta\left(y_{t+1}-p_{t+1} \hat{c}-\theta\right) & \text { if } z_{t+1}^{P}>\theta
\end{array}\right\} \\
& \equiv \phi\left(B_{t}, b_{t}^{P}, p_{t+1}\right) \\
b_{t+1}^{P} & =\beta \max \left(z_{t+1}^{P}-\theta, 0\right) \equiv \psi\left(B_{t}, b_{t}^{P}, p_{t+1}\right),
\end{aligned}
$$

where $y_{t+1}, I_{t+1}^{P}$, and $z_{t+1}^{P}$ are given by (14) and (18).

Suppose that the economy begins operating under an agrarian, closed system in which much of the labor force is absorbed by agriculture. Suppose also that underprivileged workers cannot afford to buy enough food. To be precise, agricultural employment in period $0, L_{0}=\bar{L}$, clears the food market so that

$$
F(X, \bar{L})=\lambda \hat{c}+(1-\lambda) F_{L}(X, \bar{L})<\hat{c} ; \quad \bar{L} \in(1-\lambda, 1)
$$

for which (1), (2), and (8) have been used. This condition holds when the saturation level of food consumption, $\hat{c}$, is sufficiently large, and when the amount of land, $X$, and the fraction of landowners, $\lambda$, are sufficiently small. ${ }^{23}$ The remaining labor, $1-\bar{L}$, is employed in the production of the manufactured good, which is consumed by group $R$. This means that young members of group $P$ have no voting rights and inherit nothing. Given (11), (A1), and (21), the initial transfers are

$$
B_{0}=\beta \max \left[M k_{0}^{\alpha}(1-\bar{L})-\lambda \theta, 0\right] ; \quad b_{0}^{P}=0
$$

where $k_{0}=K_{0} /(1-\bar{L})$ and the initial capital stock, $K_{0}$, is historically given.

Because the path of intergenerational transfers, $\left\{B_{t}, b_{t}^{P}\right\}_{t=0}^{\infty}$, determines all the economic variables in each period, equations (19), (20), (21), and (22) reveal that the evolution of the economy under each regime is governed by a two-dimensional, first-order, autonomous dynamical system for $B_{t}$ and $b_{t}^{P}$.

\footnotetext{
${ }^{23}$ The inequality in (A1) holds for a sufficiently large value of $\hat{c}$. This is because $F_{L}(X, \bar{L})$ decreases with $\hat{c}$. Moreover, the properties of $F(\cdot)$ ensure that $1-\lambda<\bar{L}<1$ if $X$ and $\lambda$ are sufficiently small. On the one hand, $\lim _{X \rightarrow 0} \bar{L}=\infty$ because $\lim _{X \rightarrow 0} F\left(X, L_{t}\right)=\lim _{X \rightarrow 0} F_{L}\left(X, L_{t}\right)=0$. On the other hand, $\lim _{\lambda \rightarrow 0} \bar{L}<1$ because $F(X, 1)>F_{L}(X, 1)$.
} 
Figure 3 depicts this dynamical system conditional on the stationarity of the world price $p^{w}$. The $B B$ and $b b$ loci are defined as the sets of all pairs $\left(B_{t}, b_{t}^{P}\right)$ for which $B_{t}=\phi\left(B_{t}, b_{t}^{P}, p^{w}\right)$ and $b_{t}^{P}=\psi\left(B_{t}, b_{t}^{P}, p^{w}\right)$, respectively. As was established in (12), there is no reversal of the initial ranking of wealth across dynasties. Hence, the transfer to group $P$ is below average and, thus, the pair $\left(B_{t}, b_{t}^{P}\right)$ does not cross the $45^{\circ}$ line.

\section{$5 \quad$ Trade Policy in the Growth Process}

This section analyzes the evolution of a land-scarce economy and the associated ebb and flow of protectionism reflecting gradual changes in individual trade-policy preferences and extensions of the franchise. It is shown that although the economy eventually liberalizes foreign trade, it may go through a stage of protectionism between two surges of liberalism. As shown below, this nonmonotonic transition of trade policies is consistent with the experience of 19th-century Western Europe.

Each of Regimes I and II encompasses two phases of trade policy. Regime I-A is an underdeveloped stage that is characterized by protectionism and political conflict. The landless class can only afford staple food and, thus, individuals from this class support liberal policies. These policies enable imports of inexpensive foodstuffs. However, because working class people are not sufficiently wealthy to have voting rights, political decisions are made by landowners, who support the anti-industrial, protectionist policies that protect their gains from owning land.

Trade liberalization takes place and class conflict dissipates under Regime I-B. The accumulated capital stock raises the relative importance of capital in landowners' portfolios and thereby induces them to vote for proindustrial, liberal policies. Hence, despite the fact that landless workers have no voting rights, the economy opens up to international trade, which provides workers with inexpensive foodstuffs. Although the landless cannot afford manufactured goods, their food consumption increases during the industrialization process.

Regime II-A is a semideveloped stage in which there could be a resurgence of protectionism. Now that sufficiently high wages allow all members of the economy to consume the manufactured good as well as staple food (i.e., the food constraint is not binding), individuals take into account the effects of free trade on the consumption of both goods. As a result, proindustrial policies may not benefit everyone, because the shift of labor into the manufacturing sector reduces that sector's 
labor productivity. In turn, this reduces the wage rate in terms of the manufactured good. These increasingly enfranchised workers develop political influence and, thus, the economy may return to protectionism, as did 19th-century Germany and France.

Under Regime II-B, the economy has reached a highly developed stage that features established liberalism and an absence of political conflict. In this stage, the landless not only consume the manufactured good but also leave capital to their offspring. Hence, the interest rate becomes an additional factor through which trade policy affects their incomes. The negative effect of protectionist policies on the savings rate counteracts the accompanying positive effect on wages (in terms of the manufactured good). For this reason, individuals with sufficient capital prefer free trade because it maximizes their incomes.

\subsection{Regime I: Dominance of the Landed Class}

Under this monolithic regime, both political power and economic resources are in the hands of those who own land, whereas other members of society have no voting rights and spend all their wages on consuming food. In this case, the domestic price level solely reflects landlords' preferences; i.e., $p_{t+1}=p_{t+1}^{R}$. Living standards among the poor do not improve until the economy opens up to international trade.

\subsubsection{The Trade Policy Preferences of Group $R$}

Under Regime I, the food constraint is binding for members of group $P$. It then follows from (7) and (10) that members of this group transfer nothing to their offspring, who become wage earners. Hence noting (11), the preferred price for a member of group $R$ working in period $t+1$ is,

$$
p_{t+1}^{R}=\arg \max z_{t+1}^{R}=\left[y_{t+1}-(1-\lambda) w_{t+1}-\lambda p_{t+1} \hat{c}\right],
$$

where $y_{t+1}=y\left(B_{t}, p_{t+1}\right)$ and $w_{t+1}=w\left(k\left(B_{t}, p_{t+1}\right)\right) \equiv \omega\left(B_{t}, p_{t+1}\right)$. Noting that $\partial y_{t+1} / \partial p_{t+1}=$ $y_{t+1}^{A}$, the objective function, $z_{t+1}^{R}$, exhibits convexity if the wage rate, $w_{t+1}$, is concave with respect to the relative price, $p_{t+1}$. For simplicity, the following analysis assumes convexity of the wage rate, in which case, landlords make a bilateral choice between free trade and autarky. ${ }^{24}$

Let $p_{t}^{c}$ denote the autarkic price in period $t$. Then, wage equalization (5) implies that $p_{t}^{c}=$ $w\left(B_{t} /(1-\bar{L})\right) / F_{L}(X, \bar{L})$ under Regime I. This implies that $L\left(B_{t}, p_{t}^{c}\right)=\bar{L}$ for any $B_{t}>0$. As

\footnotetext{
${ }^{24}$ Lemma 8 in the Appendix shows that if $\alpha$ is sufficiently small, $\partial^{2} w_{t} /\left(\partial p_{t}\right)^{2}<0, \forall p_{t}>p^{\min }$.
} 
shown below, $\bar{L}$ is the unique autarkic agricultural employment level under Regime I.

Lemma 1 If $(A 1)$ is satisfied and group $R$ owns all capital, $\bar{L}$ is the unique employment level that clears the goods markets under autarky in period $t \geq 0$.

Proof. See the Appendix.

It follows from (11), (17), and (A1) that a landlord (who owns capital) chooses between free trade and autarky according to

$$
\operatorname{sign}\left(v_{t}^{R, w}-v_{t}^{R, c}\right)=\operatorname{sign}\left\{\left[y_{t+1}^{M, w}-y_{t+1}^{M, c}\right]+\left[p^{w} y_{t+1}^{A, w}-(1-\lambda) w_{t+1}^{w}-\lambda p^{w} \hat{c}\right]\right\}
$$

where the superscripts $w$ and $c$ are, respectively, used to denote variables under free trade, $\left(p_{t+1}=\right.$ $\left.p^{w}\right)$, and variables under autarky, $\left(p_{t+1}=p_{t+1}^{c}\right)$, conditional on $b_{t}^{P}=0$. If one views landlords as the owners of all domestic firms, the first and second terms in the square brackets of the above expression indicate landlord gains and losses, respectively, from specialization in manufacturing. These opposing effects reflect a trade-off between the two assets - capital and land - in landlords' portfolios, and as shown below, their overall effect depends on the amount of capital relative to land.

The gain from industrial specialization that results from trade liberalization satisfies the relationship

$$
y_{t+1}^{M, w}-y_{t+1}^{M, c}>w_{t+1}^{w}\left(\bar{L}-L_{t+1}^{w}\right)
$$

which shows that there is diminishing marginal productivity of labor in manufacturing. Specialization causes the inegalitarian equilibrium (A1) to break down. This means that the value of agricultural output is insufficient to cover payments to workers, $(1-\lambda) w_{t+1}^{w}$, and landlords' food consumption, $\lambda p^{w} \hat{c}$.

Clearly, trade liberalization benefits group $R$ if it leads to a substantial shift of labor from agriculture to industry. This occurs in a land-scarce, capital abundant economy that needs a large labor force for food production under autarky and that would specialize in manufacturing under free trade. ${ }^{25}$ Landlords in such an economy would use more capital and less land to maximize their incomes. Conversely, they support anti-industrial policies when there is insufficient capital.

\footnotetext{
${ }^{25}$ Complementarity between capital and labor in manufacturing plays an important role by allowing capital accumulation to improve marginal labor productivity and thereby increase industrial employment under free trade.
} 
Let $\breve{B}$ be the critical value of $B_{t}$ for which the autarkic price, $p_{t+1}^{c}$, equals the world price, $p^{w}$. Because $p_{t+1}^{c}$ strictly increases monotonically with $B_{t}$, it follows that $p_{t+1}^{c}>p^{w}$ for $B_{t}>\breve{B}$. The following lemma states that landlords reverse their trade policy preferences in an economy that has a comparative advantage in manufacturing.

Lemma 2 If (A1) are satisfied and group $R$ owns all capital, (1) $v_{t}^{R, w}<v_{t}^{R, c}$ for a sufficiently large $B_{t}$, and $(2) v_{t}^{R, w}>v_{t}^{R, c}$ for $B_{t}=\breve{B}+\varepsilon$, where $\varepsilon>0$ is a sufficiently small value.

Proof. See the Appendix.

The transition in landlords' trade policy preferences is illustrated by Figure 4. The focus is on aggregate transfers on the interval $(\breve{B}, \infty)$, where the economy has a comparative advantage in manufacturing. The aggregate transfer, $\tilde{B}$, is defined as the critical level above which landlords prefer proindustrial liberal policy, and the existence of $\tilde{B}$ is guaranteed by Lemma 2. Landlords support anti-industrial protective policies for $B_{t} \in(\breve{B}, \tilde{B})$, where the economy has relatively little capital. ${ }^{26}$

\subsubsection{Regime I-A: Opposition to Free Trade}

Under Regime I-A $(0 \leq t \leq \tilde{t})$, the landed interests resist trade liberalization in order to protect their income sources in agriculture. Political conflicts arise between these protectionist landowners and workers, who benefit from free trade.

The Evolution of the Economy Consider an economy that initially has relatively scarce capital but a comparative advantage in manufacturing. In other words, the initial transfer, $B_{0}$ in (22), is in the neighborhood of $\breve{B}$ and satisfies

$$
\breve{B}<B_{0}<\tilde{B}
$$

Recall also that young members of group $P$ receive no transfers in period 0 ; i.e., $b_{0}^{P}=0$.

Equations (10) and (20) imply that the political state in period $t$ is Regime I if $B_{t}>b_{t}^{P}=0$. Thus, Lemma 2 implies that ${ }^{27}$

$$
p_{t+1}=p_{t+1}^{R}=p_{t+1}^{c} \quad \text { for } B_{t} \in[\breve{B}, \tilde{B}] \text { and } b_{t}^{P}=0 .
$$

\footnotetext{
${ }^{26}$ For simplicity, the figure depicts the situation in which there is a one-off reversal of trade policy preferences. It is assumed that if this is not the case, landlords continue to support anti-industrial, protective policies as long as $B_{t}$ falls into the interval $(\breve{B}, \tilde{B})$.

${ }^{27}$ It is assumed that landowners support autarkic policy when they are indifferent.
} 
It follows that the government in period $t+1$ implements the autarkic policy, which leads to the inegalitarian equilibrium (A1) and thereby to $m_{t+1}^{P}=b_{t+1}^{P}=0$. Therefore, political dominance by anti-industrial landlords persists in the early stages of development when $B_{t} \leq \tilde{B}$.

Under these circumstances, intergenerational transfers are accumulated only by the rich. Equations (21) and (A1) reveal that the evolution of aggregate transfers is

$$
B_{t+1}=\phi\left(B_{t}, 0, p_{t+1}^{c}\right)=\beta\left[M B_{t}^{\alpha}(1-\bar{L})^{1-\alpha}-\lambda \theta\right]
$$

for $B_{t} \in[\tilde{B}, \hat{B}]$ and $b_{t}^{P}=0$. This shows the monotonicity of, and decreasing returns to scale associated with, capital accumulation. The high employment level in agriculture, $\bar{L}$, generates a low wage rate, $w_{t+1} / p_{t+1}^{c}=F_{L}(X, \bar{L})$, which impedes political participation by landless wage workers. Wages do not rise until $B_{t}$ rises above $\tilde{B}$ to alter their trade-policy preferences.

It is necessary to define three critical values of aggregate transfers. First, let $\hat{B}$ be the level above which free trade releases wage workers from the food constraint; i.e., $F_{L}\left(X, L\left(\hat{B}, p^{w}\right)\right)=\hat{c}$. Second, let $B^{*}$ be the level above which wage workers bequeath to their offspring; i.e., $\omega\left(B^{*}, p_{t+1}\right)=$ $p_{t+1} \hat{c}+\theta$, where $p_{t+1}$ is given by (30) below. Third, let $B^{\prime}$ denote the level above which the freetrade policy leads to complete specialization in manufacturing; i.e., $\omega\left(B^{\prime}, p^{w}\right)=p^{w} F_{L}(X, 0){ }^{28}$ In order to exclude some potential scenarios that are beyond the scope of this paper, it is assumed that

$$
\tilde{B}<\hat{B} ; \quad B^{*}<B^{\prime}
$$

The first condition ensures that the food constraint is binding for group $P$ in the first period of trade liberalization. The second condition ensures that complete specialization occurs only in fairly advanced states of development. This implies that $\hat{B}<B^{*}{ }^{29}$ Thus, it follows from Assumptions (A2) and (A3) that, as depicted by Figure 3,

$$
\breve{B}<B_{0}<\tilde{B}<\hat{B}<B^{*}<B^{\prime}
$$

To ensure that the economy goes through the all stages of trade policy, it is assumed that the

\footnotetext{
${ }^{28}$ The condition $\tilde{B}<\hat{B}$ holds if $\hat{c}$ is sufficiently large. The condition $B^{*}<B^{\prime}$ holds if the parameter $a \in(0,1)$ in the agricultural production function (1), which represents the weight attached to land, is sufficiently large; note that $F_{L}(X, 0)=A(1-a)^{1 / \rho}$.

${ }^{29}$ The relationship $\hat{B}<B^{*}$ holds because the condition $B^{*}<B^{\prime}$ implies wage equalization of the form $F_{L}\left(X, L\left(B^{*}, p_{t+1}\right)\right)=\tilde{c}+\theta / p_{t+1}$, where $L_{t+1}=L\left(B_{t}, p_{t+1}\right)$ decreases with $B_{t}$ and increases with $p_{t+1}$.
} 
manufacturing technology, $M$, is productive enough to satisfy ${ }^{30}$

$$
B_{t}<\beta\left[\alpha M B_{t}^{\alpha}(1-\bar{L})^{1-\alpha}-\lambda \theta\right] \quad \text { for } B_{t}=\breve{B}, B^{\prime}
$$

This condition permits aggregate transfers to grow monotonically under autarky and ultimately to exceed the critical level $\tilde{B}$ - an event that changes landlords' trade preferences. The last period of Regime I-A, $\tilde{t}$, is the period in which the critical level is exceeded for the first time; i.e., $B_{t} \leq \tilde{B}$ for $t \in[0, \tilde{t})$ and $B_{t}>\tilde{B}$ for $t=\tilde{t}$. Note that between-group income inequality expands under autarky. This is because the living standards of group $P$ do not improve despite the growth in aggregate output, $y_{t}$.

Political Conflicts The first phase of Regime I is characterized by political conflict between the two income classes - groups $R$ and $P$ disagree on trade policy. Trade liberalization benefits the members of group $P$, who care only about food consumption, because specialization in manufacturing boosts the wage rate in terms of the agricultural good, $F_{L}\left(X, L_{t}\right)$. Despite the desirability of free trade for group $P$, the economy remains closed under Regime I-A to enable landlords to secure their gains from agriculture. Proposition 1 below summarizes the discussion.

Proposition 1 Under $(A 1)-(A 4)$, there is between-group conflict over trade policy $\left(\right.$ i.e., $p_{t}^{R}=p_{t}^{c}>$ $\left.p^{w}=p_{t}^{P}\right)$ for $t \in[0, \tilde{t}]$.

The Failure of Liberalization and the Poverty Trap Note that $\tilde{B}$ is the critical level for free trade and industrialization to take off. However, the economy may stagnate under Regime II-A without reaching $\tilde{B}$, depending on the availability of land. This is because the level of $X$ is an important determinant of the timing of the shift in landlords' trade-policy preferences. A rise in $X$ reduces the autarkic employment level, $\bar{L}$ in (A1), and thus lowers landlords' gains from industrial specialization. In this case, a large amount of capital is necessary for landlords to support a proindustrial, antiagricultural policy. As a result, the take-off condition (A4) is not satisfied and the economy remains autarkic and inegalitarian. ${ }^{31}$ This result indicates that there may be income

\footnotetext{
${ }^{30}$ The condition (A4) holds if $M$ is sufficiently large, noting that both $\hat{B}$ and $B^{\prime}$ approach zero as $M$ becomes infinite.

${ }^{31}$ If $X$ is sufficiently high, the economy converges to a steady-state equilibrium in which it has a comparative advantage in agriculture. This case is not discussed in this paper.
} 
differences over time between countries that have comparative advantages in manufacturing. ${ }^{32}$

\subsubsection{Regime I-B: The First Period of Globalization}

When aggregate transfers exceed $\tilde{B}$ for the first time in period $\tilde{t}$, the economy enters Regime I-B $(\tilde{t}<t \leq \hat{t})$, under which free trade, led by the landed class, is a feature. Although free trade benefits the members of group $P$, the political power is still wielded by group $R$, who own all the capital.

The Evolution of the Economy As shown by Lemma 2 and Figure 4, landlords prefer proindustrial liberal policies when aggregate transfers exceed $\tilde{B}$. Thus, it follows from $(20)$ that

$$
p_{t+1}=p_{t+1}^{R}=p^{w} \quad \text { for } B_{t}>\tilde{B} \text { and } b_{t}^{P}=0 .
$$

This means that the government in period $t+1$ implements free trade, which breaks down the inegalitarian, autarkic equilibrium (A1). Nevertheless, as long as $B_{t}$ is below $\hat{B}$, the food constraint remains binding for group $P$ (i.e., $\left.z_{t}^{P}=w_{t+1}-p_{t+1} \theta \leq 0\right)$ and, thus, $m_{t+1}^{P}=b_{t+1}^{P}=0$.

Under these circumstances, intergenerational transfers are accumulated only by the rich. Equation (21) shows that the evolution of aggregate transfers is

$$
B_{t+1}=\phi\left(B_{t}, 0, p^{w}\right)=\beta\left[y_{t+1}-(1-\lambda) w_{t+1}-\lambda\left(p^{w} \hat{c}+\theta\right)\right]
$$

for $B_{t} \in(\tilde{B}, \hat{B}]$ and $b_{t}^{P}=0$, where $y_{t+1}=y\left(B_{t}, p^{w}\right)$ and $w_{t+1}=\omega\left(B_{t}, p^{w}\right)$. The resulting growth path of aggregate transfers is above that of autarky because, as depicted by Figure 4, free trade generates higher incomes for members of group $R$, who own all the capital. Therefore, under assumption (A4) free trade permits aggregate transfers to grow monotonically and ultimately to exceed $\hat{B}$-an event that triggers political participation by members of group $P$. The final period of Regime I-B, $\hat{t}$, is the period in which the critical level is exceeded for the first time; i.e., $B_{t} \leq \hat{B}$ for $t \in[0, \hat{t})$ and $B_{t}>\hat{B}$ for $t=\hat{t}$.

Note that capital accumulation under free trade causes labor to shift from agriculture to industry, thereby increasing food consumption, $c_{t}^{P}=F_{L}\left(X, L_{t}\right) \leq \hat{c}$. Thus, unlike before, the living standards of those in group $P$ improve under Regime I-B, and, ultimately, the food constraint does

\footnotetext{
${ }^{32}$ This is in line with the work of Galor et al. (2002), who landlords' opposition to industrialization in a closed economy.
} 
not bind. Figure 5 depicts the evolution of the agricultural sector when $\delta$ is sufficiently small. Noting that $1 /(1-\delta)$ is the elasticity of substitution between land and labor, the agricultural production function (1) exhibits quasi-Leontief properties: marginal labor productivity, $F_{L}\left(X, L_{t}\right)$, is constant, except when employment is around $X$, above which it is very low. In these circumstances, $L_{t}$ decreases monotonically toward $X$ under Regime I-B and eventually falls below $X$ in period $\hat{t}+1$.

Political Conflict In the second phase of Regime I, class conflict dissipates: the two income groups agree on trade policy, even though the franchise is limited to group $R$. Opening up to international trade leads to a reduction in agricultural employment, which leads to a collapse of the inegalitarian equilibrium (A1), in which the living standards of the masses are low. The resultant improvement in the wage in terms of food, $F_{L}\left(X, L_{t}\right)$, benefits the members of group $P$, who care only about food consumption until (and including) period $\hat{t}$. For this reason, the liberal policy pursued under Regime I-B benefits the members of both groups $P$ and $R$. The discussion is summarized below.

Proposition 2 Under (A1)-(A4), there is no political conflict, and free trade is preferred by all individuals (i.e., $\left.p^{w}=p_{t}^{R}=p_{t}^{P}\right)$ for $t \in(\tilde{t}, \hat{t}]$.

\subsection{Regime II: The Rise of the Working Class}

Regime II is characterized by the political participation of members of group $P$, on whom the food constraint is no longer binding. The landless group, $P$, becomes the major political power, and the domestic price level fully reflects its preferences; i.e., $p_{t+1}=p_{t+1}^{P}$.

\subsubsection{The Trade Policy Preferences of Group $P$}

Equations (19) and (20) show that a landless member of generation $t$ prefers a price of

$$
p_{t+1}^{P}=\arg \max z_{t+1}^{P}=\left[\omega\left(B_{t}, p_{t+1}\right)+\rho\left(B_{t}, p_{t+1}\right) b_{t}^{P}-p_{t+1} \hat{c}\right]
$$

where $z_{t+1}^{P} \equiv I_{t+1}^{P}-p_{t+1} \hat{c}$. This expression incorporates two opposing effects of trade protection on the members of group $P$, who now consume the manufactured good as well as staple food. On the one hand, trade protection improves the purchasing power of the manufactured good by raising the 
wage rate, $w_{t+1}$. On the other hand, it reduces the interest rate, $r_{t+1}$, and lowers the cost of food consumption, $p_{t+1} \hat{c}$.

Because the labor allocation does not change when complete specialization develops, it is clear that $\partial I_{t+1}^{P} / \partial p_{t+1}=0$ for $p_{t+1} \leq p_{t+1}^{\min }$. By contrast, (4), (5), and (15) imply that, under incomplete specialization,

$$
\partial I_{t+1}^{P} / \partial p_{t+1}=\gamma_{t+1} F_{L}\left(X, L_{t+1}\right)\left[1-\left(1-L_{t+1}\right) b_{t}^{P} / B_{t}\right]
$$

where $p_{t+1}>p_{t+1}^{\min }$ and $\gamma_{t+1} \in(0,1)$ denotes the elasticity of the wage rate, $w_{t+1}$, with respect to price. The members of group $P$ oppose the free trade policy (i.e., $p_{t+1}^{P}>p^{w}$ ) provided that $\partial I_{t+1}^{P} / \partial p_{t+1}>\hat{c}$ for $p_{t+1}=p^{w}$. As shown below, their preferred price depends on the wage elasticity and their capital share.

First, consider the case in which $b_{t}^{P}=0$ and members of group $P$ have no capital income. It follows from (31) that $p_{t+1}^{P}>p^{w}$ if, under free trade, (1) specialization is incomplete (i.e., $\left.p^{w}>p_{t+1}^{\min }\right)$, (2) the food constraint is not binding (i.e., $\left.F_{L}\left(X, L\left(B_{t}, p^{w}\right)\right)>\hat{c}\right)$, and (3) the wage elasticity, $\gamma_{t+1}$, is sufficiently high. In fact, the last condition is satisfied if the wage rate in terms of food, $F_{L}(\cdot)$, is inelastic with respect to $L_{t+1} \cdot{ }^{33}$ Given these properties of the wage, the adverse effect of trade protection on food consumption is mitigated and, hence, wage earners are induced to vote for a protectionist policy that balances the consumption of these goods, and against free trade, which minimizes the unit cost of food.

These outcomes are illustrated by Figure 5, in which the agricultural production function incorporates a sufficiently small $\delta$ (i.e., a low elasticity of substitution between land and labor). Observe that labor productivity, $F_{L}\left(X, L_{t}\right)$, is constant unless the land-labor ratio is close to unity. Moreover, labor productivity exceeds $\hat{c}$ and the food constraint is not binding, with $L_{t}$ being sufficiently smaller than $X$. Therefore, conditions (1)-(3) above are satisfied if agricultural employment under free trade, $L\left(B_{t}, p^{w}\right)$, is positive but not too high. Given the definitions of $\hat{B}$ and $B^{*}$ in (A3), the preceding analysis can be used to establish the following lemma.

Lemma 3 If (A1)-(A4) are satisfied when $\delta$ is sufficiently small, members of group $P$ oppose free trade (i.e., $\left.p_{t+1}^{P}>p^{w}\right)$ for $B_{t} \in\left(\hat{B}, B^{*}\right)$ and $b_{t}^{P}=0$.

Note that under the assumptions of Lemma 3, wage earners are more likely to prefer free trade

\footnotetext{
${ }^{33}$ Equation (35) in the Appendix shows that $\Gamma_{t} \rightarrow \infty$ and $\gamma_{t} \rightarrow 1$ as $\delta \rightarrow-\infty$, provided that $X / L_{t}>1$.
} 
when land is scarce. ${ }^{34}$ This indicates that an abundance of land is a unique determinant of the trade policies pursued under Regime II.

Second, consider the case in which $b_{t}^{P}>0$ and the members of group $P$ have capital income, in which case, the wage elasticity matters less to them. It follows from (31) that they would prefer free trade if the ratio $b_{t}^{P} / B_{t}$, which is a measure of between-group equality, were sufficiently large and close to unity. ${ }^{35}$ The intuition behind this result is straightforward. Wealth equality diminishes between-group heterogeneity and thereby induces all individuals to maximize their average net incomes, $\left(y_{t+1}-p_{t+1} \hat{c}\right)$ in (11), when the food constraint is not binding. Pursuing free trade is the best way of meeting that objective because, as (14) implies,

$$
p^{w}=\arg \max \left[y\left(B_{t}, p_{t+1}\right)-p_{t+1} \hat{c}\right],
$$

where $B_{t}>\hat{B}$. However, because the food constraint is binding on the members of group $P$, they support free trade to maximize their food consumption. The following lemma summarizes this discussion.

Lemma 4 If $(A 1)-(A 4)$ are satisfied and $b_{t}^{P} / B_{t}$ is close to unity, the members of group $P$ support free trade; i.e., $p_{t+1}^{P}=p^{w}$.

\subsubsection{Regime II-A: Political Backlash}

As a result of industrialization under free trade, the wage rate exceeds average food expenditure, $p^{w} \hat{c}$, and the economy enters Regime II-A $\left(\hat{t}<t \leq t^{*}\right)$. Workers' growing demands for the manufactured good may trigger a resurgence of protectionism in agriculture because workers are not wealthy enough to make transfers to their offspring.

The Evolution of the Economy Recall that $B^{*}$ is the minimum level of aggregate transfers above which workers bequeath to their offspring; that is, $\omega\left(B^{*}, p_{t+1}\right)=p_{t+1} \tilde{c}+\theta$. Given the properties of $\omega\left(B_{t}, p_{t+1}\right)$, as long as $B_{t}$ is between $\hat{B}$ and $B^{*}$, the wage rate, $w_{t+1}$, is high enough for wage workers to purchase the manufactured good for consumption but not high enough to

\footnotetext{
${ }^{34}$ This is explained as follows. Given (5), it follows that $\partial L_{t+1} / \partial X>0, F_{L X}\left(X, L_{t+1}\right)>0$ and, thus, $\partial\left(X / L_{t+1}\right) / \partial X>0$ for a given pair $\left(B_{t}, p_{t+1}\right)$. Then, (35) in the Appendix shows that the wage elasticity, $\gamma_{t+1}$, increases with $X$.

${ }^{35}$ Given that linear homogeneity of the agricultural production function implies that $F_{L}\left(X, L_{t}\right) L_{t}<y_{t+1}^{A}$, a sufficiently large value of $b_{t}^{P} / B_{t}$ makes the right-hand side of (31) less than $y_{t+1}^{A}$, which represents agricultural output, and thereby less than $\hat{c}$, which denotes aggregate food consumption.
} 
make transfers to their offspring. Hence, members of group $P$ earn nothing but wage income when aggregate transfers are in this interval.

Under these circumstances, intergenerational transfers are accumulated only by the rich. Equation (21) indicates that the evolution of aggregate transfers is

$$
B_{t+1}=\phi\left(B_{t}, 0, p_{t+1}\right)=\beta\left[y_{t+1}-(1-\lambda) w_{t+1}-\lambda\left(p_{t+1} \hat{c}+\theta\right)\right]
$$

for $B_{t} \in\left(\hat{B}, B^{*}\right]$ and $b_{t}^{P}=0$, where $y_{t+1}=y\left(B_{t}, p_{t+1}\right), w_{t+1}=\omega\left(B_{t}, p_{t+1}\right)$, and $p_{t+1}=p_{t+1}^{P}$ are given in (30). Given that the wage income of an adult individual, $w_{t+1}$, is greater than his or her food expenditure, $p_{t+1} \hat{c}$, group $R$ 's total expenditure on the manufactured good, $\left[y_{t+1}-\right.$ $\left.(1-\lambda) w_{t+1}-\lambda p_{t+1} \hat{c}\right]$, exceeds its capital income, $\alpha y_{t+1}^{M}$. In addition, such high wage rates imply that agricultural employment, $L_{t+1}$, is below the autarkic level, $\bar{L}$. Therefore, Assumption (A4) implies that aggregate transfers grow monotonically to reach, then ultimately exceed, the critical level $B^{*}$-an event that triggers intergenerational transfers within group $P$. The last period of Regime II-A, $t^{*}$, is the period in which this critical level is exceeded for the first time; i.e., $B_{t} \leq B^{*}$ for $t \in\left[0, t^{*}\right)$ and $B_{t}>B^{*}$ for $t=t^{*}$. Given that there is capital accumulation under Regime II-A, and given Lemma 3, the following proposition can be established.

Proposition 3 If (A1)-(A4) are satisfied for a sufficiently small $\delta$, the economy adopts a protectionist policy (i.e., $\left.p_{t}>p^{w}\right)$ for $t \in\left(\hat{t}, t^{*}\right]$.

As shown in Figure 5, agricultural employment under Regime II-A remains below $X$ and, hence, the wage rate in terms of food, $F_{L}(\cdot)$, exceeds $\hat{c}$. Because the wage rate is inelastic, the landless wage workers prefer a protectionist policy that balances the consumption of these goods to free trade, which minimizes food expenditure. Their political influence, in addition to capital accumulation, improves their living standards over time.

Recall that wage workers in land-scarce economies are more likely to prefer free trade, as mentioned in relation to Lemma 3 . Hence, the theory developed in this paper suggests that trade policies may differ between economies under Regime II-A: Moderately land-scarce economies tend to be protectionist, whereas severely land-scarce economies maintain their liberalism. This result is consistent with O'Rourke's (1997) explanation of the difference in trade policies between England and France in the late 19th century. 
Political Conflict Regime II-A is characterized by the possibility of the revival of class conflict. As shown by (32), the no-tariff price level, $p^{w}$, maximizes the aggregate value of $I_{t+1}^{i}-p_{t+1} \hat{c}$, which can be interpreted as net income in the sense that each adult individual exclusively spends $p_{t+1} \hat{c}$ on food consumption. Given that his or her indirect utility, represented by (17), strictly increases with net income, it follows that free trade policy is preferred by at least one group. This fact, along with Proposition 3, leads to the following proposition.

Proposition 4 If $(A 1)-(A 4)$ are satisfied and $\delta$ is sufficiently small, there are between-group conflicts(i.e., $\left.p_{t}=p_{t}^{P}>p_{t}^{R}=p^{w}\right)$ for $t \in\left(\hat{t}, t^{*}\right]$.

Note that in Proposition 4, it is landowners rather than workers who support the free trade policy. This is because these homogeneous landlords are best interpreted as capitalists whose dominant income source is capital. Given a more general distribution of land ownership, landlords with extremely large land holdings would not necessarily favor free trade.

\subsubsection{Regime II-B: The Second Period of Globalization}

Aggregate transfers exceed $B^{*}$ in period $t^{*}$ and, accordingly, the economy enters Regime II-B $\left(t>t^{*}\right)$, in which a chain of intergenerational transfers emerges within group $P$. All individuals derive capital revenue and earn wages. This implies that the interest rate emerges as an additional factor through which the relative price, $p_{t+1}$, affects income, $I_{t+1}^{P}$. The adverse effect of an increase in $p_{t+1}$ on the interest rate, $R_{t+1}$, counteracts its positive effect on the wage rate, $w_{t+1}$, which causes the economy to adopt liberalism as it develops.

Conditional Dynamics For analytical purposes, first consider the evolution of transfers under

free trade as a benchmark. Given the properties of $\omega\left(B_{t}, p_{t+1}\right)$, as long as $B_{t}$ exceeds $B^{*}$, the wage rate, $w_{t+1}$, is sufficiently high for the members of group $P$ not only to consume the manufactured good but also to make transfers to their offspring. Hence, it follows from (21) that the conditional dynamical system for $B_{t}>B^{*}$ and $b_{t}^{P} \geq 0$ is

$$
\begin{aligned}
& B_{t+1}=\phi\left(B_{t}, b_{t}^{P}, p^{w}\right)=\beta\left[y\left(B_{t}, p^{w}\right)-p^{w} \hat{c}-\theta\right] ; \\
& b_{t+1}^{P}=\psi\left(B_{t}, b_{t}^{P}, p^{w}\right)=\beta\left(w_{t+1}+R_{t+1} b_{t}^{P}-p^{w} \hat{c}-\theta\right),
\end{aligned}
$$

where $\phi_{b}(\cdot)=0, w_{t+1}=\omega\left(B_{t}, p_{t+1}\right)$, and $R_{t+1}=\rho\left(B_{t}, p_{t+1}\right)$. Because aggregate wage income, $w_{t+1}$, exceeds aggregate food expenditure, $p^{w} \hat{c}$, aggregate net income, $y_{t+1}-p^{w} \hat{c}$, exceeds aggregate 
capital income, $\alpha y_{t+1}^{M}$. Hence, given Assumption (A4), aggregate transfers grow monotonically and ultimately exceed $B^{\prime}$ - an event that triggers complete specialization in manufacturing. Thus, in the long-run, landlords lose their rents and all individuals have the same income sources, wages and savings. This result indicates that an egalitarian steady-state equilibrium exists, as the following lemma states.

Lemma 5 If $(A 1)-(A 4)$ are satisfied, the conditional dynamical system (34) has a unique steadystate equilibrium, $\bar{B}=\bar{b}^{P}$.

Proof. Equations (34) and (A4) yield a unique, locally stable, steady-state level of aggregate transfers of $\bar{B}=\beta\left[y\left(\bar{B}, p^{w}\right)-p^{w} \hat{c}-\theta\right]>\max \left(B^{*}, B^{\prime}\right)$. By denoting the associated capital-labor ratio by $\bar{k} \equiv k\left(\bar{B}, p^{w}\right)$, it follows that $\phi_{B}\left(\bar{B}, b_{t}^{P}, p^{w}\right)=\beta R(\bar{k})<1$ and, thus, there is a unique steady-state level of transfers of $\bar{b}^{P}=\beta\left[w(\bar{k})+R(\bar{k}) \bar{b}^{P}-p^{w} \hat{c}-\theta\right]>0$. In the steady-state equilibrium $\left(\bar{B}, \bar{b}^{P}\right)$, complete specialization in manufacturing yields aggregate output of $y\left(\bar{B}, p^{w}\right)=w(\bar{k})+R(\bar{k}) \bar{B}$. This implies that $\bar{B}=\bar{b}^{P}$.

As (32) implies, given aggregate transfers of $B_{t}>\hat{B}$, free trade maximizes the aggregate consumption of food, aggregate consumption of the manufactured good, and aggregate transfers. That is, free trade is Pareto optimal, which is intuitive for an economy with a comparative advantage in manufacturing. However, from the microeconomic point of view, free trade may not be desirable for the members of group $P$; this depends on their capital shares, as explained in Section 5.2.1. Nevertheless, the next lemma ensures that intergenerational transfers within group $P$ grow monotonically.

Lemma 6 If $(A 1)-(A 4)$ are satisfied, $\psi\left(B_{t}, b_{t}^{P}, p^{w}\right)>b_{t}^{P}$ for $B_{t}>B^{*}$ and $b_{t}^{P} \in\left[0, \bar{b}^{P}\right)$.

Proof. See the Appendix.

Thus, free trade after period $t^{*}$ generates monotonic growth in $b_{t}^{P}$, although it is not necessarily desirable for members of group $P$. Figure 3 represents the conditional dynamical system (34) graphically. The $B B$ and $b b$ loci are defined as the set of $\left(B_{t}, b_{t}^{P}\right)$ for which $B_{t}=\phi\left(B_{t}, b_{t}^{P}, p^{w}\right)$ and $b_{t}^{P}=\psi\left(B_{t}, b_{t}^{P}, p^{w}\right)$, respectively. Given the results above, the $B B$ locus is vertical at $B_{t}=\bar{B}$ and has a unique intersection with the parabola-shaped $b b$ locus at point $\left(\bar{B}, \bar{b}^{P}\right)$. The diagram shows that choosing a free trade policy in Regime II-B results in monotonic growth of the pair $\left(B_{t}, b_{t}^{P}\right)$, 
which approaches the symmetric steady-state equilibrium, $\left(\bar{B}, \bar{b}^{P}\right)$. Hence, the following lemma can be stated.

Lemma 7 If (A1)-(A4) are satisfied, free-trade economies under Regime II-B converge to the egalitarian steady-state equilibrium given by $\bar{B}=\bar{b}^{P}$.

Note that on the transition path, aggregate output, $y_{t}$, industrial output, $y_{t}^{M}$, and the capitallabor ratio, $k_{t}$, monotonically grow, whereas agricultural output, $y_{t}^{A}$, monotonically declineseventually to zero.

Unconditional Dynamics It is now time to consider the endogenous determination of trade policy. As shown below, aggregate transfers remain sufficiently large after period $t^{*}$ and, thus, members of group $P$ retain political control over trade policy.

Proposition 5 If $(A 1)-(A 4)$ are satisfied, the economy converges to the free trade, egalitarian, steady-state equilibrium $\left(\bar{B}, \bar{b}^{P}, p^{w}\right)$.

Proof. Assumption (A4) and equation (32) ensure that $B_{t}$ remains in the interval $\left(B^{*}, \bar{B}\right)$ under Regime II-B. Given that, as shown by (30), the prevailing price level is preferred by members of group $P$, equation (12) and Lemma 6 indicate that $b_{t}^{P}$ almost reaches $B_{t}$ in the long run. Thus, it follows from Lemma 4 that the economy ultimately liberalizes foreign trade. Lemma 7 states this result.

Hence, the economy liberalizes foreign trade in the long run despite the possibility of a political backlash under Regime II-A. After the second phase of trade liberalization, which is permanent, occurs, aggregate output, $y_{t}$, industrial output, $y_{t}^{M}$, and the capital-labor ratio, $k_{t}$, monotonically increase, as described by the conditional dynamics. Note that there is necessarily complete specialization in manufacturing in the egalitarian steady-state equilibrium, in which all individual incomes comprise wages and capital revenues.

Political Conflict Because the economy converges to the egalitarian steady-state equilibrium, the theory developed in this paper implies that between-group heterogeneity and class conflict dissipate in the long run. 
Proposition 6 If $(A 1)-(A 4)$ are satisfied, there is no class conflict, and free trade policy is supported by everyone in the long run.

Proof. As the proof of Proposition 5 shows, the economy completely specializes in manufacturing under free trade in the long run. In this case, landlords have no rents and, hence, equation (31), which relates to group $R$, can be used to show that $p_{t+1}^{R}=p^{w}$, noting that $b_{t}^{R}>b_{t}^{P}$ from Lemma 12.

This result should be interpreted carefully. The eventual return to liberalism and the dissipation of class conflict should be interpreted as a predicted outcome in an unattainable stage of economic development. This is because most developed economies currently protect agriculture. In other words, it is difficult for economies to achieve trade liberalization without there being political conflict. The reason for this is that reaching such a stage of development requires highly productive technology in the industrial sector.

\section{Concluding Remarks}

This article has developed a theoretical framework for understanding the evolution of trade policy, underlying internal class conflict, and growth performance over the last few centuries. It has analyzed the dynamic interaction between trade policy and economic growth, and has thereby bridged a gap between two strands of the literature: open-economy growth theory and endogenous tariff theory. On the one hand, trade-policy preferences and the resulting trade policy depend on the stage of economic development. Because of the distributional effects of trade liberalization, income sources and income levels - both of which expand with economic development - characterize individual attitudes toward trade policy. On the other hand, engaging in international trade affects aggregate output, factor prices, and income distribution by promoting specialization in sectors in which the economy has comparative advantages. This mutual dependence between trade policy and industrialization facilitates an understanding of the evolution of economies.

Much of the paper's focus is on 19th-century Western Europe, which had a comparative advantage in manufacturing in global markets and pulled ahead of other nations through trade. Consistent with this historical experience, the theory developed in this paper argues that capital-abundant, land-scarce economies, such as those of Western Europe, experience an ebb and flow of liberalism 
during the growth process.

The first wave of liberalism is triggered by a shift in landlords' attitudes to proindustrial policies. This shift is associated with an increase in the importance of industrial capital to their portfolios. Specialization in manufacturing, which follows trade liberalization, raises aggregate output by releasing the economy from its land constraints. Trade also benefits the landless poor by providing them with inexpensive staple food.

The subsequent political backlash results from improved living standards and the accompanying political participation of newly enfranchised workers, who care about the relative prices of both capital-intensive goods and land-intensive goods. However, the retreat into protectionism is not inevitable, and different countries may pursue different trade policies in this intermediate stage of development. The paper predicts that political backlashes occur in moderately land-scarce countries but not in severely land-scarce countries. These asymmetric results on trade protection are consistent with the experience of Western Europe in the late 19th century.

The theory developed in this paper demonstrates that such economies develop through free trade, although they may retreat temporarily into protectionism. By contrast, countries in which landlords have large land holdings are likely to remain protectionist and stagnant. This is because the landed interests in these economies have a strong incentive to oppose proindustrial policies in order to protect their principal income source, which is rents. Such negative attitudes to industrialization prevent improvements in working-class living standards and, accordingly, the masses must spend most of their incomes on the consumption of staple foods, leaving no resources for savings.

Although this article has taken a novel approach to analyzing the relationship between trade policy and economic development, it ignores several aspects relevant to the world economy during the period under consideration. First, the model abstracts from technological progress, particularly improvements in transportation productivity, which has promoted the integration of global markets. Second, the analysis of this paper is limited to the direct, quantitative impacts of trade in commodities on trading economies. However, as argued by Irwin $(2001,3)$, it is important to consider Asian commodities, which were traded in small quantities, because these may have conveyed embodied new technology to Europe. Third, it is worth considering political games between trading countries that adopt strategic policies. For this purpose, it is necessary to extend the small-open economy framework, which abstracts from other countries' trade policies. Finally, this 
paper has analyzed an economy that produces a single manufactured good and, hence, has ignored the protection of manufacturing sectors. Although the paper's focus on agricultural protection is a reasonable simplification for studying European trade policy before the 20th century, it would not be appropriate for analyzing contemporary issues; currently, the protection of domestic industries would affect advanced economies more than would the protection of agricultural industries. Future research should be directed to addressing these issues.

\section{Appendix}

Lemma 8 If $\alpha$ is sufficiently small, $\partial^{2} w_{t} /\left(\partial p_{t}\right)^{2}<0, \forall p_{t}>p_{t}^{\min }$.

Proof. From (4) and (15),

$$
\frac{\partial w_{t}}{\partial p_{t}}=w^{\prime}\left(k_{t}\right) k_{p}\left(K_{t}, p_{t}\right)=\gamma_{t} F_{L}\left(X, L_{t}\right)>0 \quad \text { for } p_{t}>p_{t}^{\min }
$$

where

$$
\gamma_{t} \equiv \frac{1}{1+\alpha\left(1-L_{t}\right) \Gamma_{t}} ; \quad \Gamma_{t} \equiv-\frac{F_{L L}(\cdot)}{F_{L}(\cdot)}=\frac{1-\delta}{L_{t}+(1-a) L_{t}^{\delta+1} /\left(a X^{\delta}\right)} .
$$

Thus, the result is obtained by noting that $F_{L L}\left(X, L_{t}\right) L_{p}\left(K_{t}, p_{t}\right)<0 \forall p_{t}>p_{t}^{\mathrm{min}}$.

Proof of Lemma 1. Given that (12) implies that $c_{t}^{R} \geq c_{t}^{P}$, there are two other autarkic equilibria to be examined. If $F\left(X, L_{t}\right)=c_{t}^{R}=c_{t}^{P}=\hat{c}$, then $(A 1)$ implies that $L_{t}>\bar{L}$ and thus $c_{t}^{P}=F_{L}\left(X, L_{t}\right)<\hat{c}$, which is a contradiction. If $c_{t}^{R}\left(=I_{t}^{R} / p_{t+1}\right)<\hat{c}$, there is no aggregate demand for the manufactured good, and all workers would be employed in agriculture. Then, (A1) and (11) imply that $\lambda I_{t}^{R} / p_{t}=F(X, 1)-(1-\lambda) F_{L}(X, 1)>\lambda \hat{c}$, a contradiction.

Proof of Lemma 2. The first result follows from (23) and (24), noting that $\bar{L} \in(1-\lambda, 1)$. On the other hand, the second result is obtained by noting that $d w_{t+1}^{w} / d B_{t}>0$ and $d y_{t+1}^{w} / d B_{t}=d y_{t+1}^{M, c} / d B_{t}$ for $B_{t}=\breve{B}$ in $(23)$.

Proof of Lemma 6. If $\beta R_{t+1} \geq 1$, then (34) implies that $\psi\left(B_{t}, b_{t}^{P}, p^{w}\right)>b_{t}^{P}$ for all $b_{t}^{P} \geq 0$. If $\beta R_{t+1}<1$, then $(A 4)$ implies that $B_{t}>B^{\prime}$ and thus $L\left(B_{t}, p^{w}\right)=0$ by definition. Hence, the sign of $\psi_{B}\left(B_{t}, b_{t}^{P}, p^{w}\right)$ depends on the ratio $B_{t} / b_{t}^{P}$ in this case, implying that the conditional steady-state transfer, $b_{t}^{P}=\psi\left(B_{t}, b_{t}^{P}, p^{w}\right)$, is minimized at $B_{t}=\bar{B}$. Then, the result follows from Lemma 5 , noting that $\psi\left(B_{t}, 0, p^{w}\right)>0$ for $B_{t}>B^{*}$. 


\section{References}

Allen, Robert C., "The Great Divergence in European Wages and Prices from the Middle Ages to the First World War," Explorations in Economic History, 2001, 38, 411-447.

Aydelotte, W. O., "The Country Gentlemen and the Repeal of the Corn Laws," English Historical Review, January 1967, 82 (322), 47-60.

Bairoch, Paul, "European Trade Policy, 1815-1914," in Peter Mathias and Sidney Pollard, eds., The Cambridge Economic History of Europe, Vol. VIII, Cambridge: Cambridge University Press, 1989, pp. 1-160.

Baldwin, Richard E., Philippe Martin, and Gianmarco I. P. Ottaviano, "Global Income Divergence, Trade, and Industrialization: The Geography of Growth Take-Offs," Journal of Economic Growth, March 2001, $6,5-37$.

Barnes, Donald Grove, A History of the English Corn Laws, New York: Augustus M. Kelley, 1965.

Ben-David, Dan and Michael B. Loewy, "Free Trade, Growth, and Convergence," Journal of Economic Growth, June 1998, 3, 143-170.

Blattman, Christopher, Jason Hwang, and Jeffrey G. Williamson, "The Terms of Trade and Economic Growth in the Periphery 1870-1983," Working Paper 9940, National Bureau of Economic Research, Cambridge, MA 2003.

Coppel, J. and M. Durand, "Trends in Market Openness," Working Paper 221, OECD Economics Department, Paris 1999.

De Vries, Jan, Economy of Europe in an Age of Crisis 1600-1750, Cambridge, UK: Cambridge University Press, 1976.

Findlay, Ronald and Kevin H. O'Rourke, "Commodity Market Integration, 1500-2000," Working Paper 8579, National Bureau of Economic Research, Cambridge, MA November 2001.

Flora, Peter, Jens Alber, and Franz Kraus, State, Economy, and Society in Western Europe 1815-1975, Vol. I, Frankfurt: Campus Verlag, 1983.

Fohlen, Claude, "France, 1700-1974," in Carlo M. Cipolla, ed., The Fontana Economic History of Europe, Vol. 4(1), London: Collins/Fontana, 1973, chapter 2, pp. 7-75.

Galor, Oded and Andrew Mountford, "Trade, Demographic Transition, and the Great Divergence: Why are a Third of People Indian or Chinese?," Mimeo, January 2003.

and David N. Weil, "Population, Technology, and Growth: From Malthusian Stagnation to the Demographic Transition and Beyond," American Economic Review, September 2000, 90 (4), 806-828.

and Omer Moav, "From Physical to Human Capital Accumulation: Inequality and the Process of Development," Review of Economic Studies, October 2004, 71 (4), 1001-1026.

, _ _ and Dietrich Vollrath, "Land Inequality and the Emergence of Human Capital Promoting Institutions," Brown University Economics Working Paper No. 05-03. http://ssrn.com/abstract=670883 February 222005.

Glamann, Kristof, "European Trade 1500-1750," in Carlo M. Cipolla, ed., The Fontana Economic History of Europe, Vol. 2, London: Collins/Fontana, 1974, chapter 6, pp. 427-526.

Goodfriend, Marvin and John McDermott, "Early Development," American Economic Review, March 1995, 85 (1), 116-33.

Grossman, Gene M. and Elhanan Helpman, "Protection for Sale," American Economic Review, September 1994, 84 (4), 866-850.

Hansen, Gary D. and Edward C. Prescott, "Malthus to Solow," American Economic Review, September 2002, 92 (4), 1205-17. 
Hoffman, Phillip T., David S. Jacks, Patricia A. Levin, and Peter H. Lindert, "Real Inequality in Europe Since 1500," Journal of Economic History, June 2002, 62 (2), 322-355.

Irwin, Douglas A., "Welfare Effects of British Free Trade: Devate and Evidence from the 1840s," Journal of Political Economy, December 1988, 96, 1142-1164.

_ _ "Political Ecnomy and Peel's Repeal of the Corn Laws," Economics and Politics, Spring 1989, 1, $41-59$.

_ , "Comments on Ronald Findlay and Kevin O'Rourke," in "Globalization in Historical Perspective," The University of Chicago Press, 2001.

Kindleberger, Charles P., "Group Behavior and Internatinal Trade," Journal of Political Economy, February 1951, 59 (1), 30-46.

_ _ "The Rise of Free Trade in Western Europe, 1820-1875," Journal of Economic History, March 1975, 35 (1), 20-55.

Kogel, Tomas and Alexia Prskawetz, "Agricultural Productivity Growth and Escape from the Malthusian Trap," Journal of Economic Growth, 2001, 6, 337-357.

Kohn, Meir, "The Expansion of Trade and the Transformation of Agriculture in Pre-Industrial Europe," in "The Origins of Western Economic Success: Commerce, Finance, and Government in Pre-Industrial Europe," mimeo, available online at www.dartmouth.edu/ mkohn/, 2001a.

, "Trading Costs and the Pattern of Trade in Pre-Industrial Europe," in "The Origins of Western Economic Success: Commerce, Finance, and Government in Pre-Industrial Europe," mimeo, available online at www.dartmouth.edu/ mkohn/, 2001b.

Kriedte, Peter, Peasants, Landlords and Merchant Capitalists, Cambridge: Cambridge Unviersity Press, 1983.

Lamartine Yates, Paul, Forty Years of Foreign Trade, New York: Macmillan, 1959.

Leontief, Wassily W., "Domestic Production and Foreign Trade: The American Capital Position ReExamined," Proceedings of the American Philosophical Society, September 1953, 97 (4), 332-349.

Lindert, Peter H. and Jeffrey G. Williamson, "Does Globalization Make the World More Unequal?," Mimeo, May 2001.

Maddison, Angus, The World Economy: A Millennial Perspective, Paris: the OECD Development Centre, 2001.

Magee, Stephen P., William A. Brock, and Leslie Young, Black Hole Tariffs and Endogenous Policy Theory, Cambridge: Cambridge University Press, 1989.

Mayer, Wolfgang, "Endogenous Tariff Formation," American Economic Review, December 1984, 74 (5), 970-985.

McDermott, John, "Mercantilism and Modern Growth," Journal of Economic Growth, March 1999, 4, 55-80.

, "Development Dynamics: Economic Integration and the Demographic Transition," Journal of Economic Growth, 2002, 7, 371-409.

Minchinton, Walter, "Patterns of Demand 1750-1914," in Carlo M. Cipolla, ed., The Fontana Economic History of Europe, Vol. 3, London: Collins/Fontana, 1973, chapter 2, pp. 77-186.

_ - "Patterns and Structure of Demand 1500-1750," in Carlo M. Cipolla, ed., The Fontana Economic History of Europe, Vol. 2, London: Collins/Fontana, 1974, chapter 2, pp. 83-176.

Nash, R. C., "South Carolina and the Atlantic Economy in the Late Seventeenth and Eighteenth Centuries," Economic History Review, November 1992, 45 (4), 677-702.

Ormrod, David, The Rise of Commercial Empires: England and the Netherlands in the Age of Mercantilism, 1650-1770, Cambridge, UK: Cambridge University Press, 2003. 
O'Rourke, Kevin H., "The European Grain Invasion, 1870-1913," Journal of Economic History, 4 1997, 57, 775-801.

, "British Trade Policy in the 19th Century: A Review Article," European Journal of Political Economy, 2000, 16, 829-842.

, "Globalization and Inequality: Historical Trends," Working Paper 8339, National Bureau of Economic Research, Cambridge, MA June 2001.

, Alan M. Taylor, and Jeffrey G. Williamson, "Factor Price Converegence in the Late Nineteenth Century," International Economic Review, August 1996, 37 (3), 499-530.

and Jeffrey G. Williamson, Globalization and History, Cambridge, MA: The MIT Press, 1999.

and __ , "When Did Globalization Begin?," Working Paper 7632, National Bureau of Economic Research, Cambridge, MA April 2000.

and __ "After Columbus: Explaining the Global Trade Boom 1500-1800," Working Paper 8186, National Bureau of Economic Research, Cambridge, MA March 2001.

and __ , "From Malthus to Ohlin: Trade, Growth and Distribution Since 1500," Mimeo, February 2003.

Pomeranz, Kenneth, The Great Divergence, Princeton, NJ: Princeton University Press, 2000.

Rogowski, Ronald, Commerce and Coalitions: How Trade Affects Domestic Political Arrangements, Princeton, NJ: Princeton University Press, 1989.

Sachs, J. D. and A. Warner, "Economic Reform and the Process Fof Global Integration," in "Brookings Papers on Economic Activity," Vol. I, Washington, D.C.: Brookings Institution, 1995.

Scheve, Kenneth F. and Matthew J. Slaughter, "What Determines Individual Trade-Policy Preferences?," Journal of International Economics, 2001, 54, 267-292.

Schonhardt-Bailey, Cheryl, "Specific Factors, Capital Markets, Portfolio Diversification, and Free Trade: Domestic Determinants of the Repeal of the Corn Laws," World Politics, July 1991, 43 (4), 545-569.

Taylor, Alan M., "Globalization, Trade, and Development: Some Lessons From History," Working Paper 9326, National Bureau of Economic Research, Cambridge, MA November 2002.

Thompson, F. M. L., "Business and Landed Elites in the Nineteenth Century," in F. M. L. Thompson, ed., Landowners, Capitalists, and Entrepreneurs: Essays for Sir John Habakkuk, New York: Oxford University Press, 1994, chapter 5, pp. 139-170.

Trefler, Daniel, "The Case of the Missing Trade and Other Mysteries," American Economic Review, December 1995, 85 (5), 1029-1046.

Williamson, Jeffrey G., "The Impact of the Corn Laws Just Prior to Repeal," Explorations in Economic History, 1990, 27, 123-156.

, "Is Protection Bad for Growth? Will Globalization Last? Looking for Answers in History," Mimeo, 2002a.

, "Land, Labor, and Globalization in the Third World, 1870-1940," Journal of Economic History, March 2002b, 62 (1), 55-85.

, "Winners and Losers over Two Centuries of Globalization," Working Paper 9161, National Bureau of Economic Research, Cambridge, MA September 2002c.

_ - "Stolper-Samuelson, Strategic Tariffs and Revenue Needs: World Tariffs 1789-1938," Mimeo, June 2003.

Woodruff, William, "The Emergence of an International Economy," in Carlo M. Cipolla, ed., The Fontana Economic History of Europe, Vol. 4(2), London: Collins/Fontana, 1973, chapter 11, pp. 656-737. 


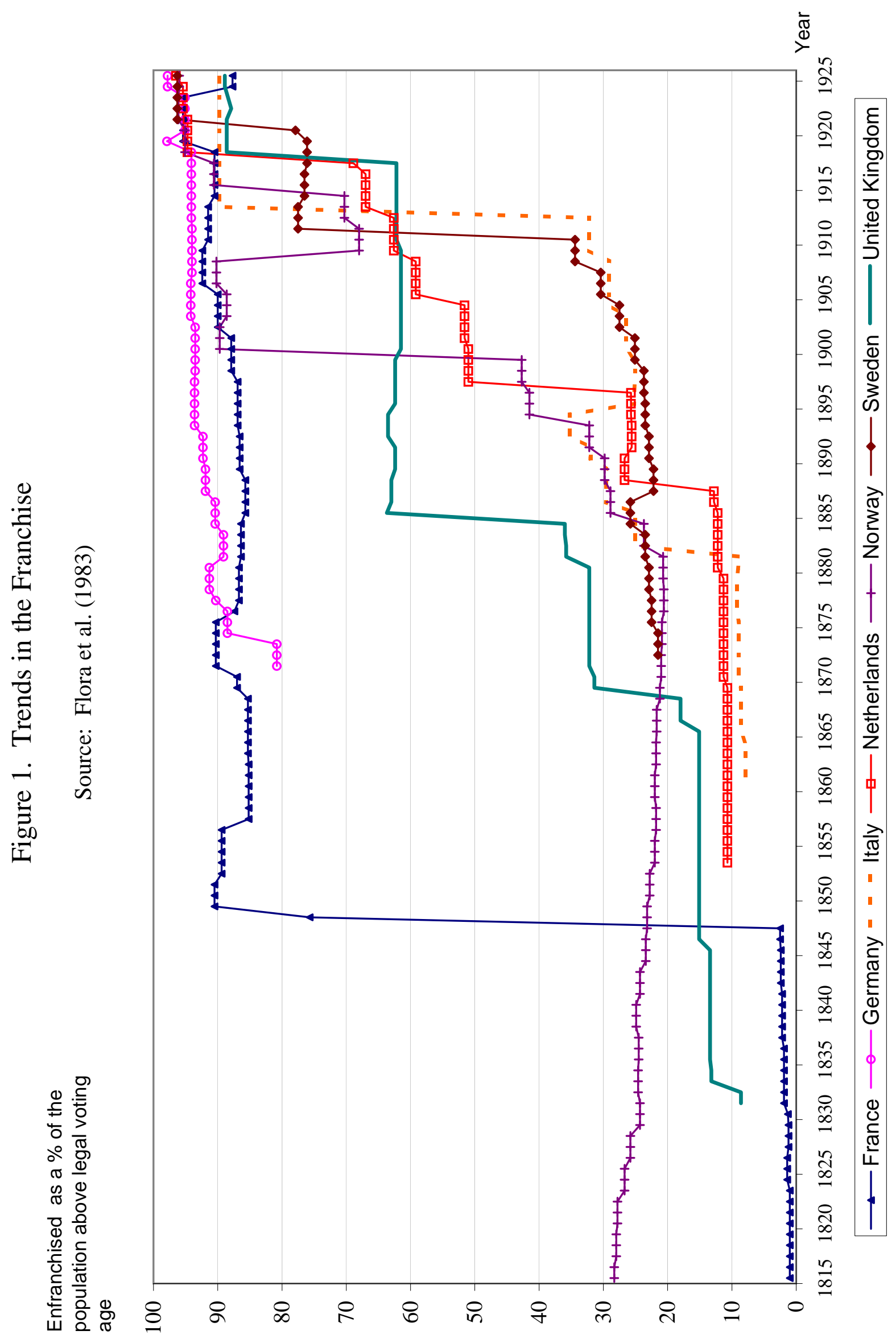




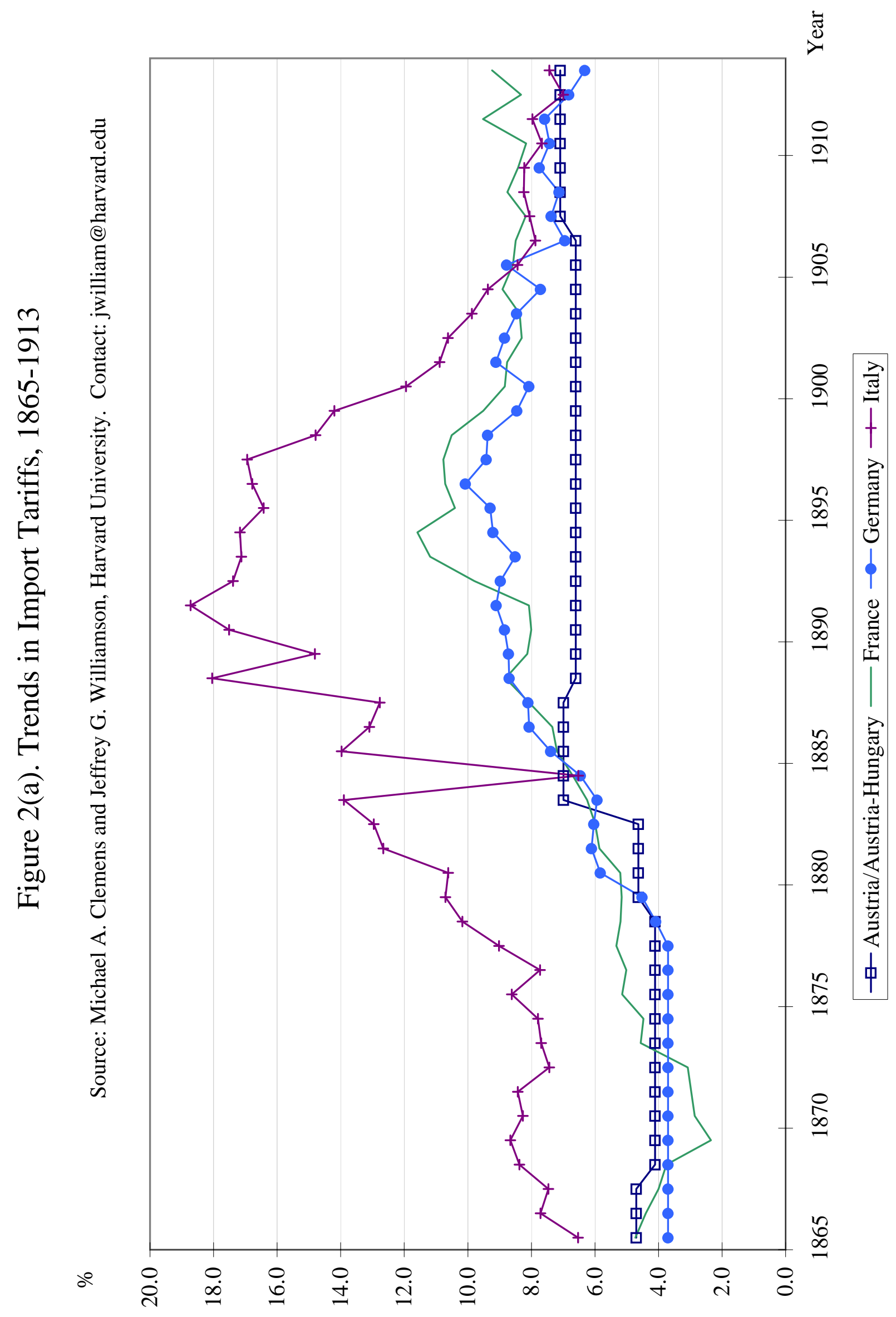




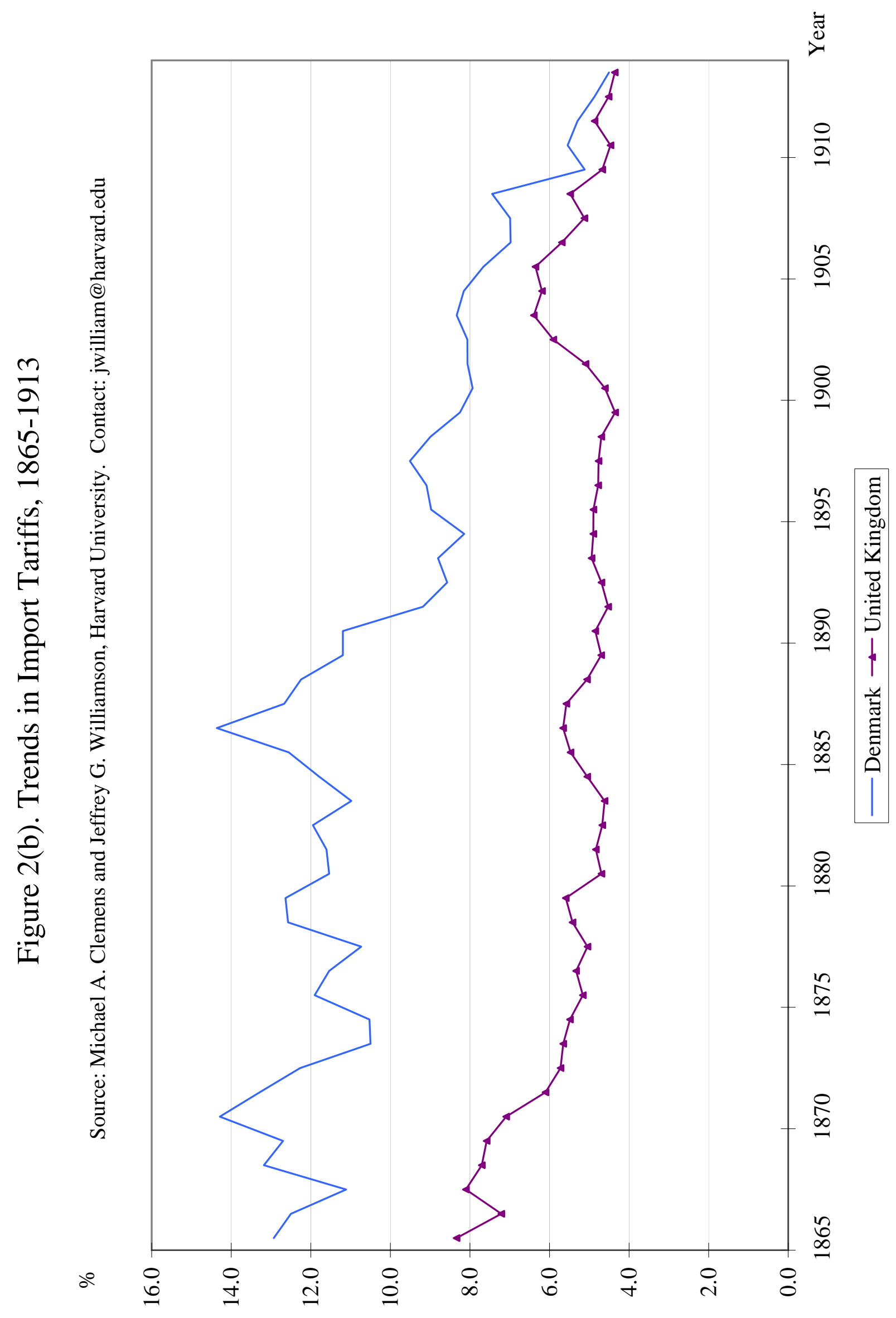




$$
\text { N }
$$




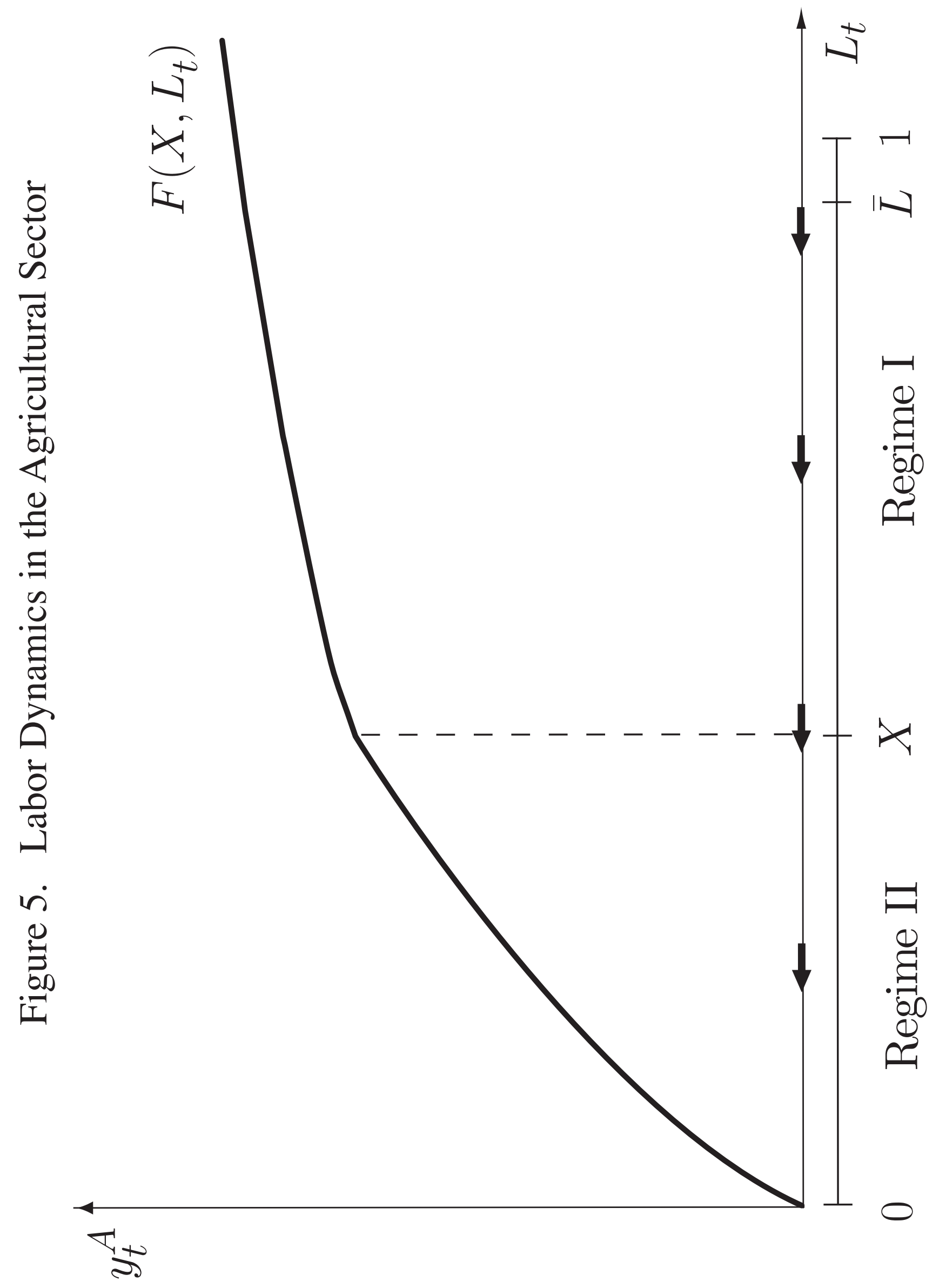

